\title{
THE EFFECT OF EDUCATION ON MORTALITY AND HEALTH: EVIDENCE FROM A SCHOOLING EXPANSION IN ROMANIA
}

\author{
Ofer Malamud \\ Andreea Mitrut \\ Cristian Pop-Eleches \\ Working Paper 24341 \\ http://www.nber.org/papers/w24341 \\ NATIONAL BUREAU OF ECONOMIC RESEARCH \\ 1050 Massachusetts Avenue \\ Cambridge, MA 02138 \\ February 2018
}

We would especially like to thank Andreea Balan-Cohen for her work on the schooling reform in Romania for a different project that is still in progress. Andreea Mitrut gratefully acknowledge support from Jan Wallanders and Tom Hedelius Fond. We have benefited from comments by participants at the ERMAS 2017 and the CHERP conference at the Federal Reserve Bank of Chicago. All errors are our own. The views expressed herein are those of the authors and do not necessarily reflect the views of the National Bureau of Economic Research.

NBER working papers are circulated for discussion and comment purposes. They have not been peer-reviewed or been subject to the review by the NBER Board of Directors that accompanies official NBER publications.

(C) 2018 by Ofer Malamud, Andreea Mitrut, and Cristian Pop-Eleches. All rights reserved. Short sections of text, not to exceed two paragraphs, may be quoted without explicit permission provided that full credit, including $(\odot$ notice, is given to the source. 
The Effect of Education on Mortality and Health: Evidence from a Schooling Expansion in Romania

Ofer Malamud, Andreea Mitrut, and Cristian Pop-Eleches

NBER Working Paper No. 24341

February 2018

JEL No. I1,I12,I15,I25,I26

\section{ABSTRACT}

This paper examines a schooling expansion in Romania which increased educational attainment for successive cohorts born between 1945 and 1950. We use a regression discontinuity design at the day level based on school entry cutoff dates to estimate impacts on mortality with 1994-2016 Vital Statistics data and self-reported health with 2011 Census data. We find that the schooling reform led to significant increases in years of schooling and changes in labor market outcomes but did not affect mortality or self-reported health. These estimates provide new evidence for the causal relationship between education and mortality outside of high-income countries and at lower margins of educational attainment.

Ofer Malamud

School of Education and Social Policy

Northwestern University

Annenberg Hall

2120 Campus Drive

Evanston, IL 60208

and NBER

ofer.malamud@northwestern.edu

Andreea Mitrut

University of Gothenburg

Department of Economics

Box 640

40530 Göteborg, Sweden

andreea.mitrut@economics.gu.se
Cristian Pop-Eleches

The School of International and Public Affairs

Columbia University

1401A International Affairs Building, MC 3308

420 West 118th Street

New York, NY 10027

and NBER

cp2124@columbia.edu 


\section{Introduction}

There is substantial evidence showing that more educated people have better health and longer life expectancies. However, whether this correlation reflects a causal relationship remains an open question. A number of recent papers have used changes in compulsory schooling requirements to identify the causal impact of schooling on health and mortality in the United States (Lleras-Muney, 2005; Mazumder, 2008), the United Kingdom (Oreopoulos, 2006; Clark and Royer, 2013), Denmark (Arendt, 2008), France (Albouy and Lequien, 2009), the Netherlands (van Kippersluis, et al., 2011), and Sweden (Meghir, et al., forthcoming). While this empirical approach can be compelling, the findings have been mixed and sometimes contradictory, even when based on the same educational expansions. Moreover, all of these studies are focused on the United States or Western Europe where compulsory schooling laws usually affect students enrolled in secondary school. As a result, we know relatively little about the causal effect of education on health and mortality in developing or middle-income countries, and at lower margins of educational attainment.

This paper examines the impact of a schooling expansion in Romania during the late 1950s and early 1960s, which sought to provide all students with at least 7 years of compulsory education. We show that successive cohorts of individuals, born between 1945 and 1950, who were affected by this schooling expansion, experienced rising educational attainment. Then we use a regression discontinuity design at the day level to compare individuals born just before the school entry cutoff of January 1 to those born just after, who were almost identical in age but began school later and therefore had greater opportunities to extend their education. Since students born immediately before and after January 1 were also the oldest and youngest in their respective classes, 
we also draw on cohorts born after the schooling expansion had concluded to separate the effect of increased education from that of relative age and starting school younger. ${ }^{1}$

We demonstrate that the schooling expansion led to significant increases in years of schooling for the affected cohorts born between 1945 and 1950. This increase in educational attainment was accompanied by significant increases in labor force participation and decreases in fertility for women. Nevertheless, using detailed information on deaths from Vital Statistics data between 1994 and 2016, we do not find evidence that the schooling expansion reduced the mortality of affected cohorts up to the age of 71. Nor are there reductions in mortality from more specific causes of death. In addition, there are no significant effects for measures of self-reported health using data from the 2011 Romanian Census.

Our findings indicate that more education does not help individuals avoid or postpone deaths during middle and old age. This is consistent with the null results in the most recent papers by Clark and Royer (2013) and Meghir et al. (forthcoming) for the United Kingdom and Sweden. However, to the best of our knowledge, this is the first paper to provide compelling estimates for the causal relationship between education and mortality outside of high-income countries and at lower margins of educational attainment. We do not interpret these estimates as an argument against further educational expansions in the developing world. But they do suggest the need to be more circumspect about the potential for such expansions to improve health and increase life expectancy, at least at lower margins of educational attainment.

\footnotetext{
${ }^{1}$ See Cascio and Schanzenbach (2016) for evidence on the impacts of relative age in Tennessee and Black, Devereux, and Salvanes (2011) for evidence on the effect of starting school younger in Norway.
} 
The paper is organized as follows. Section 2 reviews the related literature.

Section 3 provides a background of the Romanian educational system and the educational expansion. Section 4 describes the data and the empirical strategy. Section 5 presents the results, alternative explanations and potential mechanisms, while Section 6 concludes.

\section{Related Literature}

This section reviews some of the previous literature estimating the causal impact of education on health and mortality. We begin with a more detailed discussion of the papers that take advantage of changes in compulsory schooling requirements. Then we describe some of the alternative empirical approaches used for identifying the causal effect of education at higher margins of educational attainment. For more detailed reviews of these and other studies, see Mazumder (2012) and Galama et al. (2018).

For the United States, Lleras-Muney (2005) uses Census data to examine the impact of changes in compulsory schooling laws between 1915 and 1939 that affected students over 14 years of age. Her instrumental variables (IV) estimates indicate that an additional year of schooling leads to significant declines in the probability of dying in the next 10 years. In a follow-up study, Mazumder (2008) notes that these results are not robust to including state-specific trends but presents evidence from the Survey of Income and Program Participation (SIPP) showing positive impacts of education on selfreported health status. Finally, Black et al. (2016) argue that virtually all of the variation in mortality rates is captured by cohort effects and state effects, making it difficult to 
reliably estimate the effects of changing educational attainment due to state-level changes in compulsory schooling. ${ }^{2}$

For the United Kingdom, Clark and Royer (2013) use changes to British compulsory schooling laws in 1947 and 1972 that increased the minimum school leaving age from 14 to 15 and then from 15 to 16 . Their regression discontinuity (RD) design does not provide strong evidence for an impact of education on mortality or other health outcomes. Davies et al. (2016) re-examine the 1972 change in compulsory schooling using UK Biobank data and find a statistically significant decline in mortality but their results are somewhat sensitive to functional form.

Other studies are focused on European countries: For Sweden, Meghir et al. (forthcoming) do not find improvements in mortality and other health measures for affected cohorts following an educational reform in Sweden that raised the number of years of compulsory schooling from $7 / 8$ to 9 , eliminated early selection based on academic ability, and introduced a national curriculum. Arendt (2005) and Albouy and Lequien (2009) also find no statistically significant impact of compulsory school reforms on health outcomes in Denmark and France, respectively. Yet van Kippersluis et al. (2011) do find that increasing compulsory school beyond grade 6 in the Netherlands leads to significant reduction in mortality in old age.

Finally, a different set of studies use draft avoidance behavior in the United States during the Vietnam War to estimate the impact of college education on mortality and health outcomes. Buckles et al. (2016) show that the increased college going among men in cohorts associated with greater draft avoidance also leads to lower mortality in

\footnotetext{
${ }^{2}$ In a paper that considers the effect of school quality on health, Aaronson et al. (2017) find that childhood exposure to Rosenwald schools in the Jim Crow south increased life expectancy, after accounting for the negative effects of migration.
} 
subsequent years. Grimard and Parent (2007) and de Walque (2007) use a similar identification strategy to estimate impacts on smoking behavior and find evidence suggesting that more education reduces the take-up of smoking and current smoking. However, the estimates in these papers are based on changes at the margin of college education, which may differ from changes due to compulsory schooling laws.

In our own review of the literature, and in those by Mazumder (2012) and Galama et al. (2018), we have not found any papers that provide compelling causal estimates for the impact of education on health or mortality in low and middle-income countries.

\section{Background on Education in Romania}

During the post-war period, the structure and the organization of education in Romania was largely based on the model in the Soviet Union as codified by Decree No. 175 of 1948 (Braham, 1972). ${ }^{3}$ There were several different types of schools. First, there were 4-year primary schools that offered grades 1 through 4 and were often located in rural areas. Second, there were 7-year general schools, called gymnasiums, which offered grades 1 through 7 (and later expanded to grade 8), with the first four years covering similar material as in the 4- year primary schools. Third, there were 11-year schools, which offered grades 1 through 11 in one school that provided both primary and secondary education.

After a successful campaign to provide basic literacy education targeted towards all ages in the late 1940s and early 1950s, the government focused its attention on increasing enrollment beyond the first four grades. According to Giurescu et al. (1971, p.

\footnotetext{
3 This section relies heavily on information provided in Barham $(1963,1972)$.
} 
351), the five year plan of 1955-1960 specified that the extension of compulsory schooling to 7 years was to be given special attention by the party and government. Thus, the directives of the Communist Party's Second Congress of 1955 which outlined the second five year plan, envisioned a "situation under which, by 1960-1961, the fifth grade would enroll 90 percent of the 4-year school graduates, and under which, according to the Third Five Year plan, the 7-year school would be universal and compulsory. At first only the first four grades were made compulsory, but villages and rural communities having 7-year schools were required by virtue of Decision No. $1035 / 1958$ to make the 7 year schooling period universal beginning with the 1958 1959 academic year" (Braham, 1963).

Nevertheless, this process was not immediate and was constrained by a lack of enough schools offering 7 years of compulsory schooling: "Since this governmental action applied only to places where 7-year schools already existed, it appears that the extension of free compulsory education is to a large extent only nominal. Furthermore, with rural communities retaining the 4-year compulsory level, the lack of detailed planning to elevate their schools to the 7-year compulsory level has left an irregular pattern of schooling in the provinces" (Braham, 1963). Filipescu and Oprea (1972) also confirm the gradual process of expanding education at the gymnasium level. They explain that the expansion of 7-year compulsory education began in 1956 within towns and larger villages that already had schools beyond the 4th grade, and that it gradually expanded until it was close to universal by 1961-1962.

We can document some of these changes using aggregate data on enrollment from the Annual Statistics of the Socialist Republic of Romania. Figure 1 shows the large increase in the number of students graduating from gymnasium between 1955 and 1965. During this period, graduation from gymnasiums increased sharply from 116,698 
in 1959 to 329,739 in 1963 and stayed at similar levels through the late 1960s and early 1970s.

Further evidence for these dramatic changes can be observed at the cohort level. By law, students entered grade 1 in September of the year following the calendar year in which they reached 6 years of age. Thus, the cohort born in 1945 was 6 years of age in 1951, entered first grade in the fall of 1952, entered fifth grade in the fall of 1956 and would have graduated with 7 years of schooling in the spring of 1959. This cohort should be the first cohort that could have been affected by the policy reform. Similarly, the cohort born in 1947 was the first cohort to have potentially benefited from the 1958 Government Decision that made 7-year of schooling compulsory. Finally, the cohort that entered fifth grade in 1961-1962, which according to Filipescu and Oprea (1972) is the first cohort to have achieved universal 7 year compulsory education, was born in 1950 .

Figure 2 shows the highest educational attainment by year of birth for cohorts of individuals in the Romanian Census of 1992. There is a sharp decline in the proportion of individuals with primary education between cohorts born in 1944 and 1950. At the same time, we observe a sharp increase in the proportion of individuals who complete secondary education (which includes graduates of gymnasiums). Note that cohorts born between 1935 and 1944 also experienced large increases in educational attainment. This is mainly driven by the early literacy and education campaigns introduced after the Communist government came to power.

In Figure 3 we plot the "residual" percent of individuals born between 1943 and 1955 who completed primary education by their month of birth, after accounting for calendar month of birth effects. A number of interesting patterns emerge from this graph. First, and consistent with the results in Figure 2, we observe the large decrease in the proportion of students who have only primary education for those born between 
1945 and 1950. Secondly, and more importantly for our empirical strategy, the decreases in percent of students with only primary education occur discontinuously, with disproportionately large decreases for those born after January 1st in this period. The discontinuities are especially visible for those born around January 1st of 1945, 1947, 1948 and 1949 and to a smaller extent for those born around January 1st of 1946 and 1950. At the same time, no similar discontinuities are visible for the control cohorts born between 1950 and 1953. The patterns in Figure 3 suggest that we can use detailed information on date of birth to estimate the impact of these educational expansions using a regression discontinuity design.

To summarize, the evidence on graduation rates from gymnasiums in the aggregate data coincides with the cohort analysis of educational attainment in the 1992 Census; and both are broadly consistent with the historical record of educational reforms in Romania. Together, they indicate that education levels past the first 4 years of primary schooling started to expand in the 1956-1957 school-year and by 19611962, enrollment in the 5th grade was essentially universal. In other words, the expansion affected cohorts born starting in 1945 and universal gymnasium education was essentially completed for cohorts born in or after 1950.

\section{Data and Empirical Strategy}

\subsection{Data}

Our main sample consists of individuals born in Romania between 1944 and 1952. Those born from 1945-1949 were enrolled in the affected grades during the period of schooling expansion while those born from 1950-1952 were enrolled after the 
expansions had already been completed. ${ }^{4}$ We put together information on these cohorts from several different datasets.

We use the 1992 Romanian Census, when individuals were 40 to 48 years of age, to estimate the impact of the schooling reform on educational attainment; certain labor market outcomes, and conduct specification checks of our empirical strategy. ${ }^{5}$ Two features make this dataset especially useful for our analysis: First, with 35,000 to 45,000 observations in each yearly birth cohort, we have sufficient power to employ a regression discontinuity design. Second, there is detailed information about the day, month, and year of birth so we can identify the discontinuity induced by the policy within a narrow window.

The 1992 Census provides detailed information about the highest level of educational attainment for each respondent according to the following categories: none, primary, gymnasium, secondary education, post-secondary, and university education. For simplicity, we impute years of schooling by assigning the number of years associated with each level of education. ${ }^{6}$ This serves as our main summary measure of education when estimating the impact of the schooling expansion. The Census also has information on socio-economic characteristics of our respondents, such as gender, ethnicity, and region of birth. We use these variables to validate our research design. Finally, it contains information on labor force participation and occupational status (for

\footnotetext{
${ }^{4}$ We use the three subsequent cohorts born immediately after the end of the schooling expansion as our preferred comparison group both because they are most similar in age to the cohorts affected by the schooling expansion and offer sufficiently large samples. However, our results are essentially unchanged when we use four, five, or six subsequent cohorts as our comparison group.

5 This is a 15\% random sample taken from the full Romanian Census by the Population Activities Unit (PAU) of the United Nations Economic Commission for Europe (UNECE). 6 We also use data collected by the Romanian National Statistics Institute in 1995 and 1996 with reports of actual years of schooling (rather than educational attainment) in order to validate our imputed measure of years of schooling. These data come from surveys based on the 1994 World Bank's Living Standards Measurement Studies (LSMS) for Romania.
} 
those employed) as well as the fertility of women, which serve as useful auxiliary outcomes.

Panel A of Table 1 presents summary statistics for the individuals in cohorts born between 1944 and 1952. The average age at the time of the 1992 census is 42.2 years and the fraction of female respondents is almost exactly half. Almost 90 percent of the sample is ethnic Romanian, with about 7 percent ethnic Hungarians, and about 1.5 percent are Roma. The average imputed years of schooling in our sample is 9.58 years.

We use the 1994-2016 Vital Statistics Mortality files (VSM) to estimate the impact of the schooling expansion on mortality. These data cover the universe of deceased persons in Romania with detailed information about their socio-economic characteristics, including the day of birth/death and the main cause of death. Thus, we can observe mortality for the cohorts used in our analysis between the ages of 42 and 71 by day and year of birth. ${ }^{7}$ We compute mortality for the cohorts born between 1944 and 1952 by dividing the total deaths of these cohorts during the period 1994-2016 to the population at risk defined here as the 1944-1952 cohorts (alive) at the 1992 census. $^{8}$

Our calculation of the mortality rate may differ from the true mortality because of migration in and out of Romania. The number of immigrants (for the cohorts we study here) is close to zero and should not affect our results. Moreover, the VSM files include all people deceased abroad as long as they still have a Romanian residence and/or citizenship. Therefore, our mortality files should account for the majority of the Romanian migrants abroad who are temporary emigrants and do not change their

\footnotetext{
${ }^{7}$ Lleras-Muney (2005) and Clark and Royer (2013) suggest that the largest effects of education on mortality occur before the age of 64. Life expectancy in Romania was 69.5 years in 1994, 74.2 in 2011, and 75.5 years in 2016.

${ }^{8}$ We use sample weights to calculate the total population because we only have a $15 \%$ census sample.
} 
permanent residence. ${ }^{9}$ But we also directly examine the potential for bias due to migration by checking whether schooling expansion affects the probably of migration.

The VSM file provides detailed information on the main cause of death so we are able to look separately at deaths associated with circulatory diseases and cancer. These are the two most important causes of death in Romania, accounting for $44.6 \%$ and $26.5 \%$ respectively of all deaths. Similar to Meghir et al. (2017) we also reclassify diseases according to the epidemiological literature as preventable and treatable; preventable causes of death may reflect health behaviors while the treatable causes of death may be related to access to healthcare. ${ }^{10}$

Panel B of Table 1 shows the overall mortality rate and the mortality rate by category for our main sample. Approximately 26 percent of our sample died between 1994-2016. The largest category of deaths was due to circulatory diseases which account for 10.5 percentage points, followed by cancer and preventable deaths, at 47.7 and 5.9 percentage points respectively. Treatable diseases only accounted for 3.9 percentage points.

Finally, we use the 2011 Romanian Census to compute a self-reported measure of health, which provides the impact of the schooling expansion on individuals who survived until 2011. All respondents are asked whether they have any health related problems that may affect their daily life at work, school, at home, etc. Approximately 7.6 percent of people in our cohorts of interest reported having such problems. Those who answered affirmatively were given a set of six follow-up questions - whether they were (i) visually, (ii) hearing, or (iii) movement impaired, (iv) whether they had any memory

\footnotetext{
${ }^{9}$ According to Statistics Romania these emigrants are the vast majority (over the 95\%) of emigrants. 10 We use the ICD 10 codes for defining cancer, circulatory diseases and treatable and preventable causes of death. See the Notes at the end of the tables for more information.
} 
or concentration problems, (v) self-care or (vi) difficulties in communication with their peers.

\subsection{Empirical Strategy}

As described earlier, the schooling expansions in Romania occurred over a five year period from 1956 to 1961 and affected born between 1945 and 1950. Since the government rapidly expanded access to schooling during this period, a child born just after January 1 would have benefited from the additional schools slots created by the government over the course of a year, as compared to a child born just before January 1 who would have been part of an earlier cohort. Indeed, the discontinuities in the fraction of individuals whose highest level of education was primary school were clearly visible in Figure 3 for the years 1945, 1947, 1948 and 1949. In this section, we estimate these discontinuities more formally using a regression discontinuity (RD) design.

We estimate the differences across successive cohorts during the period of educational expansion (i.e. in the "treatment years" of 1945-1950) using the following equation:

$$
y_{i}=\beta^{\prime} X_{i}+\alpha A F T E R_{i}+f\left(d a y_{i}\right)+\varepsilon_{i}
$$

where $y_{i}$ is an outcome such as education or mortality for individual $i, X_{i}$ is a set of control variables, $A F T E R_{i}$ is an indicator for individuals born just after the school entry cutoff of January 1 , and $f\left(d a y_{i}\right)$ is a parametric or non-parametric function of the day of birth which serves as our running variable. For simplicity, our preferred specifications do not include any control variables except for a constant, although including them does not affect our results. The coefficient on $\alpha$ is an estimate for the effect of being born just after the school entry cutoff on the relevant outcome. When the outcome is a measure of 
education, such as years of schooling, it represents a "first stage" estimate; when the outcome is a measure of health, such as mortality, it represents the "reduced-form" estimate.

If we assume that the exclusion restriction holds (i.e. that being born after the school entry cutoff affects mortality only through years of schooling), the ratio of the reduced-form and first stage coefficients represents an estimate for the impact of education on mortality. However, the exclusion restriction may not hold since those individuals born just after the school entry cutoff are generally the oldest children in their class; that is, if relative age has an independent effect on health or mortality.

In order to account for any independent effect of relative age, we also compare individuals who were born just before and after the school entry cutoff in a period without educational expansion (i.e. in the "control years" of 1950-1953). We do this by estimating a regression equation similar to equation (1) above using this set of control years. But we also estimate the following models that directly compare the impact of being born just after the school entry cutoff in treatment years to control years:

$$
y_{i}=\beta^{\prime} X_{i}+\alpha A F T E R_{i}+\gamma T R E A T_{i}+\delta A F T E R_{i} * T_{R E A T}+f\left(\text { day }_{i}\right)+\varepsilon_{i}
$$

where $T R E A T_{i}$ is an indicator for individuals born during years of educational expansion 1945-1950, and the other variables are defined as before (with some abuse of notation). In this specification, the coefficient on the interaction term, $\delta$, yields the impact of being born just after the school entry cutoff during treatment years over and above the effect in control years that did not experience educational expansions.

A key consideration when implementing a regression discontinuity design is the functional form of the forcing variable, $f\left(d a y_{i}\right)$. We present estimates using a local linear regression as suggested by Hahn, Todd, and van der Klaauw (2001). The choice of 
the window is somewhat arbitrary as we need to strike a balance between the advantages of having more precise estimates with larger windows and mitigating the possibility of confounding time effects with more narrow windows. Therefore, for our main tables we present specifications using a 180, 120, 90, 60 and 30 day intervals, as well as the Imbens-Kalyanarman (IK) optimal bandwidth (Imbens and Kalyanarman, 2012). We also confirm that our results are robust to using parametric specifications that include higher order polynomials such as linear, quadratic and cubic trends in day of birth (results available by request). All regressions cluster on day of birth in order to avoid the problems associated with specification error in the case of discrete covariates (Lee and Card, 2008).

A common specification check for the regression discontinuity design is to verify that the density of observations is continuous around the cutoff (McCrary, 2008). When we examine the density, we find substantial heaping on January 1 and on some of the days immediately preceding it. ${ }^{11}$ We believe that this heaping is due to delays in the reporting of births that occurred during the holiday period between Christmas and New Year's Day when government offices were closed. ${ }^{12}$

Insofar as this type of heaping is similar for our "treatment" and "control" years, we can account for this issue in the regression that uses both sets of years. However, we also attempt to deal with this issue using a "donut-RD" design as suggested by Barreca, Lindo, Waddel (2016). In particular, we present all of our results when dropping individuals born within 7 days of January 1 in order to be symmetric around the cutoff. Results are qualitatively similar when we exclude individuals born more than one week

\footnotetext{
11 These density tests are shown in Appendix Table 1 and Appendix Figure 1. They are structured in a similar fashion to the main tables as described in the results section.

12 Indeed, it appears the spike in observations occurs on January 2 in years when January 1 is a Sunday.
} 
before or after January 1 or when we exclude individuals born only one or several days before January 1 (available by request). ${ }^{13}$

\section{Results}

\subsection{Effects on educational attainment}

We begin by estimating the impact of the schooling expansion on years of completed schooling based on the level of education recorded in the 1992 Census. These "first stage" results are shown in Table 2 which has three panels: Panel A presents estimates for $\alpha$ from equation (1) using the treatment years, 1945-1950; Panel B presents estimates for $\alpha$ from equation (1) using the control years, 1950-1953; Panel C presents estimates for $\alpha$ and $\delta$ from our preferred specification (2) which includes both treatment and control years. Columns (1) to (6) in each panel show estimates for alternative bandwidths. These include 180,120, 90, 60 and 30 days of the January 1 cutoff, as well as the optimal bandwidth proposed in Imbens and Kalyanaraman (2012). Columns (7) to (12) show analogous specifications that exclude observations within 7 days of the January 1 cutoff (i.e. 7 day donut-RD regressions).

Panel A of Table 2 indicates that each successive cohort during the school expansion period 1945-1950 received an additional 1/5 to 3/5 years of schooling; the point estimates for the impact of being born just after vs. just before the January 1 cutoff in the treatment years range from 0.21 to 0.67 years of schooling using our different bandwidths. In contrast, the estimates in Panel B showing the impact of being born just after vs. just before January 1 in the control years of 1950-1953 are small and

\footnotetext{
${ }^{13}$ We also verify that our available covariates vary smoothly around the discontinuity in Appendix Tables 2 and 3 . With a few exceptions, the coefficients are mostly small and insignificant.
} 
statistically insignificant in all specifications. Panel C shows estimates from the specification that combines both treatment and control years. In these specifications, the impact of the school expansion is captured by $A F T E R_{i} * T R E A T_{i}$ and shows impacts of 0.23 to 0.59 years of schooling, all highly significant. The results using the donut specifications are about 30\% smaller in magnitude but still statistically significant in all specifications. ${ }^{14}$ The range of these estimate is not altogether surprising given the large number of different specifications that we consider. However, we take our preferred specification to be the IK bandwidth for the full sample, implying a first stage effect of approximately a $1 / 2$ year of schooling.

We also present our "first stage" results graphically in Figure 4. Panels A, C and E plot average years of schooling by day of birth for individuals born six months before and after January 1st of each year; panels B, D and F plot the same data by week of birth, which often makes it easier to discern the patterns. The graphs are normalized so that day 1 corresponds to January 1 and week 1 corresponds to the week of January 1 to January 7. The fitted lines are based on smoothed local linear regressions using the IK bandwidth.

Panels A and B show a clear discontinuity after January 1 for the treatment years of 1945-1950. This visual evidence confirms that individuals born merely a couple of days apart received a substantially different amount of schooling as a result of the school expansion. In contrast, panels $\mathrm{C}$ and $\mathrm{D}$ of Figure 4 reveal no change in average educational attainment before and after January $1^{\text {st }}$ in the control cohort. Nevertheless, each of the first four panels in Figure 4 show some time trends, consistent with the

\footnotetext{
${ }^{14}$ Appendix Table 4 uses the 1994-1996 LSMS datasets to estimate the impact of the schooling expansion on reported years of schooling rather than an imputed measure based on completed educational levels. The results are somewhat less precise but generally similar to those in Table 4.
} 
presence of seasonality in the timing of births. Such time effects are not visible in Panels E and F of Figure 4, which use both treatment and control years to estimate a version of equation (2) that differences out the impacts in the control years from those in the treatment years.

\subsection{Effects on mortality and self-reported health}

In this section we analyze whether, in addition to affecting education, the school expansion policy had an impact on mortality and health. We begin by using the Vital Statistics data from 1994 to 2016 to examine mortality. Table 3, which has the same structure as the previous tables, reveals no evidence of a statistically significant effect of being born just after vs. just before the January 1 cutoff on mortality in the treatment years of 1945-1950 (in Panel A) or in the control years of 1950-1953 (in Panel B), except for the smallest bandwidths. Furthermore, all of the significant effects disappear once we consider the donut regression that excludes individuals born 7 days before and after January 1.

We see a couple of marginally significant effects on $A F T E R_{i} * T R E A T_{i}$ in Panel C that includes both treatment and control years, although these have positive signs. Still, with 10 out of the 12 point estimates from our preferred specification in Panel C not showing any statistically significant effect, we conclude that there is no evidence for an impact of the schooling expansion on mortality. Given the standard errors for our full sample, we can rule out with $95 \%$ confidence that the schooling expansions reduced mortality by more than 0.8 percentage points between 1994-2016 when the average mortality rate was 26 percent.

A graphical analysis of the mortality results is presented in Figure 5, structured similarly to the preceding figures. The patterns in Panels A-F provide a visual 
interpretation of the regression estimates from Table 3. We do not see evidence for large discontinuities in the mortality rate between 1994 and 2016 and, if anything, they point against the finding that education reduces mortality.

We also consider the effect of the schooling expansion on specific causes of death. We first focus on mortality from the two most common causes of death in Romania: cancer and circulatory diseases. The regression estimates for these causes of death are shown in Tables 4 and 5 respectively, while the figures are shown in Appendix Figure 2 and 3 respectively. We also classify certain causes of death as preventable or treatable, similar to Meghir et al. (2017). The regression estimates for these causes of death are shown in Appendix Table 5 and 6 respectively. In none of the tables do we observe evidence for a consistent effect of the schooling expansion on mortality. Similarly, none of the corresponding graphs show visible discontinuities around the regression discontinuity cutoffs. Thus, we do not find any more evidence for the impact of the schooling expansion on specific causes of death than on the mortality rate as a whole.

In addition to the impact of the schooling expansion on mortality, we also examine its effect on self-reported health using the 2011 Romanian Census. This is shown in Table 6 and Appendix Figure 4, which are again structured in a similar fashion to the previous tables and figures. Overall, we do not find an impact of the schooling expansion on self-reported health among individuals who survived until 2011. It is worth noting that, since we have access to the full $100 \%$ sample of the 2011 Census, these results are estimated with substantial precision. Given our standard errors for the full sample, we can rule out with 95\% confidence that the schooling expansions reduced the fraction of people with health related problems by 0.06 percent, which corresponds to 0.023 standard deviation units. We have also explored the specific dimensions of 
health used to create our self-reported health index (i.e. vision, hearing, impaired movement, memory, self-care and communication) and did not find any meaningful impacts for these specific categories.

\subsection{Alternative explanations}

\subsubsection{Quality of education}

Despite the clear impacts of the schooling reform on educational attainment, one might question the quality of this education (especially in light of the rapid expansion of education during these early years) and ask whether the expansion also had an impact on other important outcomes.

Table 7 presents estimates for the impact of the schooling expansions on labor force participation, measured as an indicator for being employed at the time of the 1992 Census. ${ }^{15}$ This table is structured similarly to the other tables, with Panels A, B, and C showing impacts for the treatment years, control years, and all the years together. The impact of the schooling expansion is most clearly visible in Panel A of Table 7 which shows that individuals entering school in successive cohorts are 1.2 to 1.6 percent more likely to be employed. ${ }^{16}$ These impacts are less robust in Panel $\mathrm{C}$ and in the donut regressions, but the patterns are largely consistent. A graphical depiction of these impacts can be seen in Panels A, B, E and F of Appendix Figure 5.

We also observe significant impacts of Romania's schooling expansion on fertility, as shown in Appendix Table 7. Our preferred estimates reported in Panel C using the full sample of women show that exposure to the expansion decreased fertility

\footnotetext{
15 Unfortunately, the 1992 Census does not contain any information about earnings or income. 16 We also found impacts on occupational composition, such as the likelihood of working in a manual occupation or the skill level associated with one's occupation. These are available by request.
} 
by 0.08 and 0.29 children. To summarize, these labor market and fertility effects suggest that the educational expansion had an impact on a range of socio-economic outcomes.

\subsubsection{Migration}

To address concerns about bias due to migration, we consider whether our school expansion directly affected the probability of external migration. The 2011 census contains information on all persons who migrated abroad for a period of at least 12 months (at the time of the census). So the vast majority of the Romanian emigrants are covered; i.e., all individuals working abroad who maintain their houses, identity cards or/and remain registered by the Romanian administrative bodies. ${ }^{17}$ Using a similar strategy as before, we show in Appendix Table 8 that there is no impact of the schooling expansion on the likelihood of the individuals (who survived until 2011) to emigrate.

The migration results presented above, while reassuring, are not able to capture any possible effects of the schooling expansion on permanent migration. We address this possibility through an indirect test. Using information from the 1992 and 2011 census samples, we calculate the (weighted) number of people born in a given day who are in the 2011 census as a (weighted) fraction of the number in the 1992 census. This ratio should capture a combination of both mortality and migration between 19922011. These results are presented in Appendix Table 9, and confirm that there is no impact of the school expansion on this combined measure of mortality and migration.

\footnotetext{
17 According to Statistics Romania, about 95\% of the Romanian emigrants are temporary migrants, meaning that they keep their Romanian ID's. Moreover, the death of these individuals is reported in the Romanian Mortality Files. While permanent migrants who do not remain registered by the Romanian administrative bodies are not covered, we believe this is a second-order issue because these are mostly highly educated migrants (university or more) who, most likely, were not affected by our policy.
} 


\subsection{Mechanisms}

Our findings indicate that the Romanian schooling expansion did not improve health or reduce mortality. In this section, we attempt to explore some of the mechanisms underlying these findings. However, insofar as education can impact health and mortality through many different channels, our discussion remains largely speculative.

First, more education may lead to higher income and perhaps better health care. While Romania has universal access to the public healthcare system independently of the individual income, financial resources may still be important because of informal payments (i.e. bribes). Our main results did suggest that the schooling expansion led to greater labor market opportunities (e.g. higher employment) but the Census data did not include information on income. In Appendix Table 10, we use the LSMS survey to examine whether the impact of the school expansion affected income and found positive but insignificant effects. Note that, using the LSMS data, we find positive and significant impacts of the schooling expansion on employment, similar to the results using Census data. ${ }^{18}$

Second, even if more education would lead to higher incomes, the impact of income on health is not obvious. Income could allow individuals to access better health care, but it may also lead to an increased consumption of unhealthy goods, such as alcohol and cigarettes. This seems to be the case in Romania where, using the Romanian Household Budget Survey, we find positive and significant correlations between

\footnotetext{
${ }^{18}$ Education could also affect mortality through changes in the occupation structure. Indeed, we observe some evidence that Romania's schooling expansion, shifted individuals out of manual jobs and farming and into technicians and professional jobs. However, whether these changes should have led to improved health is not completely clear if more education enables individuals to find work in more skilled occupations, with better working conditions, we might expect to find positive health impacts. However, some skilled occupations may be associated with more stress than certain less skilled occupations. Moreover, it is possible that some relatively skilled manufacturing jobs may have worse working conditions than jobs in the informal sector such as agriculture.
} 
education and smoking. However, when we attempted to estimate our regression discontinuity specifications using this data, we find no significant effects of education on smoking behavior (see Appendix Table 11). ${ }^{19}$ Using the same data, we also find no effects on the likelihood of having a chronic condition. ${ }^{20}$

Thus, our analysis does not yield any strong conclusions about the role of particular mechanisms in explaining our results. ${ }^{21}$ However, these results need to be interpreted with care since they are mostly based on imprecise estimates using small auxiliary datasets.

\section{Conclusion}

This paper analyzes a schooling expansion in Romania, which aimed to ensure that all students received at least 7 years of compulsory schooling. The schooling expansion affected five consecutive cohorts born between 1945-1950 and we use a regression discontinuity (RD) design to estimate impacts by comparing the differences across successive cohorts of affected students. We find that beginning school in a (one year) later cohort increases educational attainment by approximately a $1 / 2$ year of schooling. We do not find any consistent significant impacts of the schooling reform on selfreported health or mortality. Moreover, we can rule out that the schooling expansions reduced mortality by more than 0.08 percentage points between 1994 and 2016 or that

\footnotetext{
${ }^{19}$ Specifically, we use the 2001-2009 Romanian Household Budget Survey (RHBS) which is a national representative survey, covering about 30,000 households each year and contains detailed socio-economic information on all household members. Note that the RHBS data does not have the day of birth, but only the month and year and therefore we cannot show the donuts specifications.

20 The RHBS data also showed no effect on the likelihood of being hospitalized or on the number of days hospitalized during the last 30 days (results available by request).

${ }^{21}$ Given the findings in Aaronson et al. (2017), we also examined the role of internal migration. However, we did not find significant effects of the schooling expansion on internal migration, measured as an indicator for whether the person lives in the locality of birth in 2011 (results available upon request).
} 
they improved self-reported health by more than 0.02 standard deviation units for the full sample of individuals in the affected cohorts.

Whether education causally affects health and mortality is an important question for both developed and developing countries alike. However, most of the previous work has focused on the United States and Western Europe. The findings in this literature are mixed and there is not strong evidence that education significantly improves health or decreases mortality. We extend the literature by estimating causal impacts for a population that is substantially poorer and also experienced changes at a lower margin of educational attainment. However, our findings only serve to reinforce the absence of a causal effect of education health and mortality, even in this setting. While we have attempted to examine the underlying mechanisms for these findings, more work needs to be done to better understand why we do not observe a strong relationship between education and health across a variety of different settings. 


\section{References}

Daniel A., B. Mazumder, S.G. Sanders, and E. Taylor (2017) "Estimating the Effect of School Quality on Mortality in the Presence of Migration: Evidence from the Jim Crow South". SSRN working paper.

Albouy, V. and l. Lequien (2009) "Does Compulsory education lower mortality?" Journal of Health Economics, 28(1): 155-168.

Arendt, J.N. (2005) "Does education cause better health? A panel data analysis using school reforms for identification." Economics of Education Review, 24(2):149 -160.

Barreca, A., J. Lindo, and G. Waddel (2016) "Heaping- Induced Bias in RegressionDiscontinuity Designs” Economic Inquiry, 54(1): 268-293.

Black, D. A., Hsu, Y. C. \& Taylor, L. J. (2015). "The effect of early-life education on later-life mortality". Journal of Health Economics, 44, 1-9.

Black, S.E., P.J. Devereux, and K.G. Salvanes (2011) "Too young to leave the nest? The effects of school starting age". Review of Economics and Statistics 93(2):455-467

Braham, R. L. (1963) Education in the Rumanian People's Republic. Washington, D.C : U.S. Dept. of Health, Education, and Welfare, Office of Education.

Braham, R.L., 1972. Education in Romania: A Decade of Change. US Government Printing Press.

Buckles, K., A. Hagemann, O. Malamud, M. Morrill, and A. Wozniak (2016) "The effect of college education on mortality" Journal of Health Economics, 50: 99-114.

Cascio, E.U. and D. W. Schanzenbach (2016) "First in the Class? Age and the Education Production Function" Education Finance and Policy 11(3): 225-250.

Clark, D. and H. Royer (2013) "The effect of education on adult mortality and health: Evidence from Britain" The American Economic Review, 103(6), 2087-2120.

Davies, N. M., Dickson, M., Smith, G. D., Van den Berg, G. \& Windmeijer, F. (2016) "The causal effects of education on health, mortality, cognition, well-being, and income in the UK Biobank". bioRxiv 074815. Preprint.

De Walque, D. (2007) “Does education affect smoking behaviors? Evidence using the Vietnam draft as an instrument for college education" Journal of Health Economics $26(5), 877-895$.

Filipescu, V. and Oprea O. (1972) Invatamantul obligatoriu in Romania si in alte tari. Editura Didactica si Pedagogica, Bucuresti 
Galama, T.J., A. Lleras-Muney, H. van Kippersluis (2018) "The Effect of Education on Health and Mortality: A Review of Experimental and Quasi-Experimental Evidence”. NBER Working Paper No. 24225

Giurescu, C, I Ivanov and N. Mihaileanu, editors (1971) Istoria învăţământului din România : compendiu. Editura Didactică şi Pedagogică, Bucuresti

Grimard, F. and D. Parent (2007) "Education and smoking: Were Vietnam war draft avoiders also more likely to avoid smoking?" Journal of Health Economics, 26 (5), 896926.

Hahn, J., Todd, P. and van der Klaauw (2001) "Identification and Estimation of Treatment Effects with a Regression-Discontinuity Design” Econometrica, 69 (1): 201-209.

Imbens, G. and K. Kalyanaraman (2012) "Optimal Bandwidth Choice for the Regression Discontinuity Estimator" Review of Economic Studies 79, 933-959.

Lee, D.S., and D. Card (2008) "Regression discontinuity inference with specification error" Journal of Econometrics, 142, 655-674.

Lleras-Muney, A. (2005) “The Relationship Between Education and Adult Mortality in the United States" Review of Economic Studies, 72, 189-221.

Mazumder, B. (2008) "Does Education Improve Health: A Reexamination of the Evidence from Compulsory Schooling Laws” Economic Perspectives, 33(2), 2-16.

Mazumder, B. (2012) "The effects of education on health and mortality" Nordic Economic Policy Review No. 1, 261-302.

Meghir, C., M. Palme and E. Simeonova (2017) "Education, Health and Mortality: Evidence from a Social Experiment" forthcoming, American Economic Journal: Applied Economics

Oreopoulos, P. (2006) "Estimating Average and Local Average Treatment Effects of Education when Compulsory School Laws Really Matter" American Economic Review 96(1), 152-175.

van Kippersluis, H. O. O’Donnell and E. van Doorslaer (2011) "Long-Run Returns to Education: Does Schooling Lead to an Extended Old Age?" Journal of Human Resources 46(4): 695-721. 


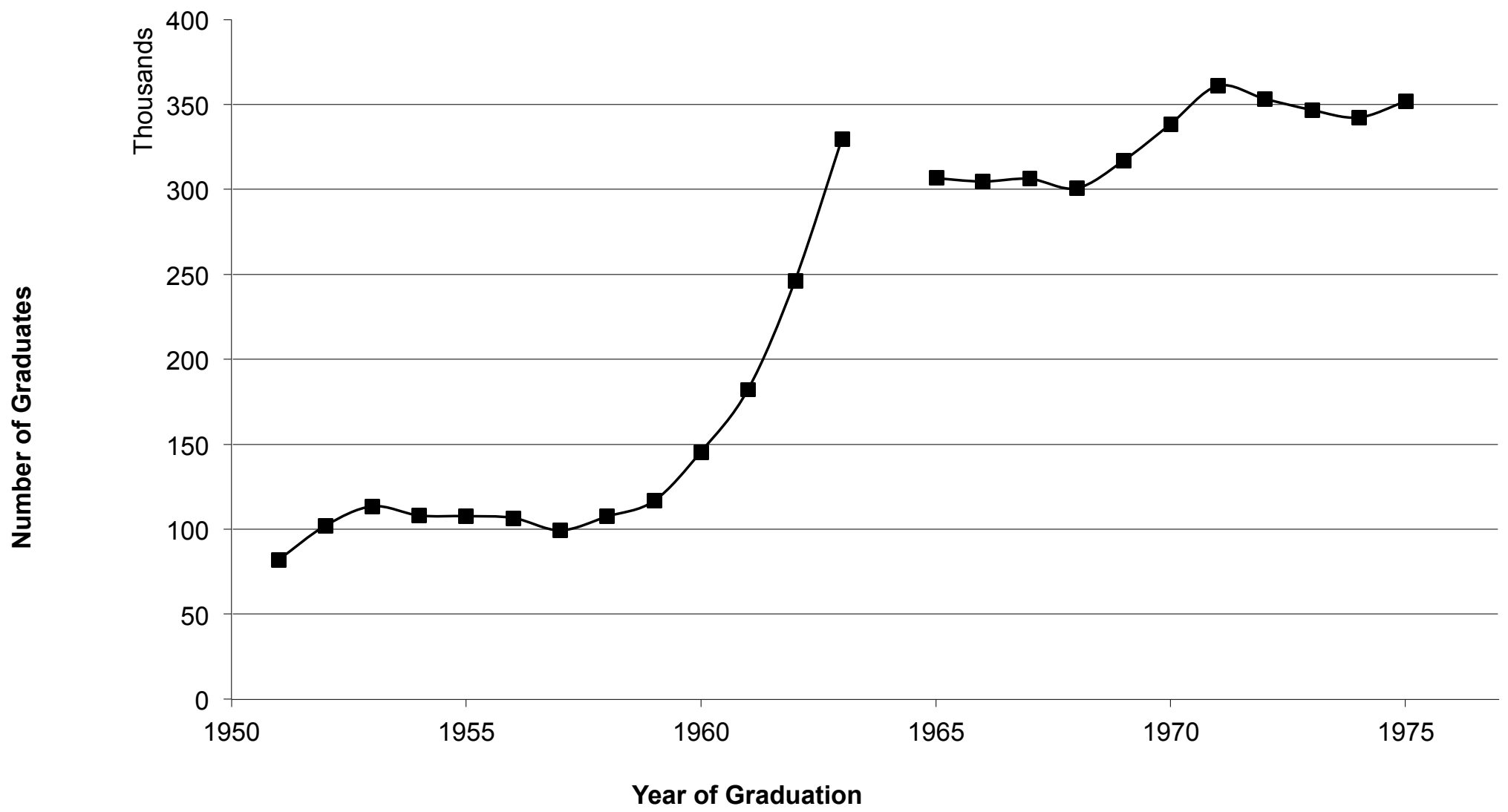

FIGURE 1: Graduates from Gymnasium Schools by Year of Graduation

Notes: Figure 1 plots the number of students graduating from gymnasium between 1951 and 1971.

Source: Romanian Statistical Yearbook 
Figure 2: Educational achievements in Romania by year of birth

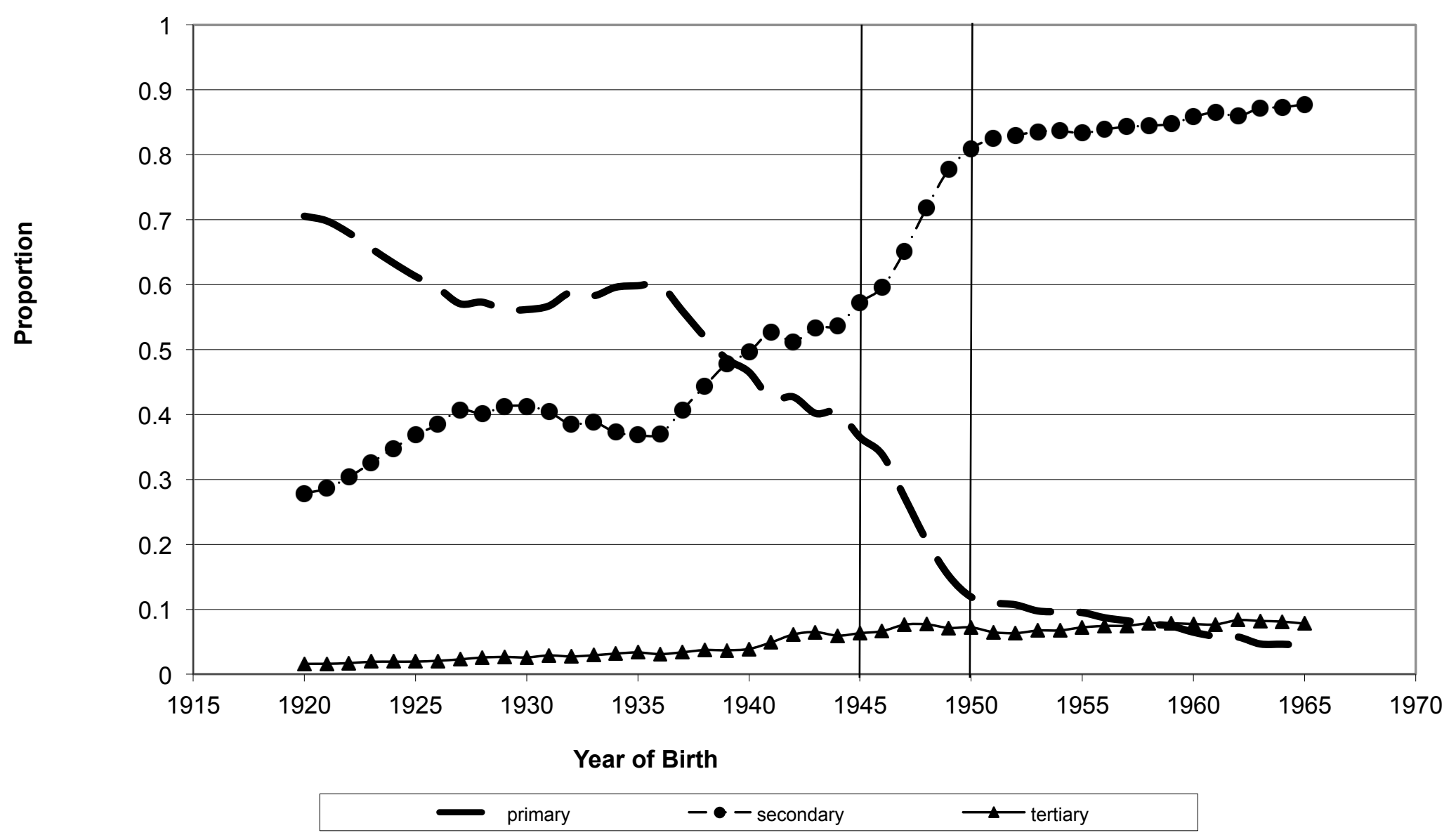

FIGURE 2: Educational achievements in Romania by year of birth

Notes: Figure 2 plots the the highest educational attainment by year of birth for cohorts of individuals.

Source: 1992 Romanian Census (PAU sample) 


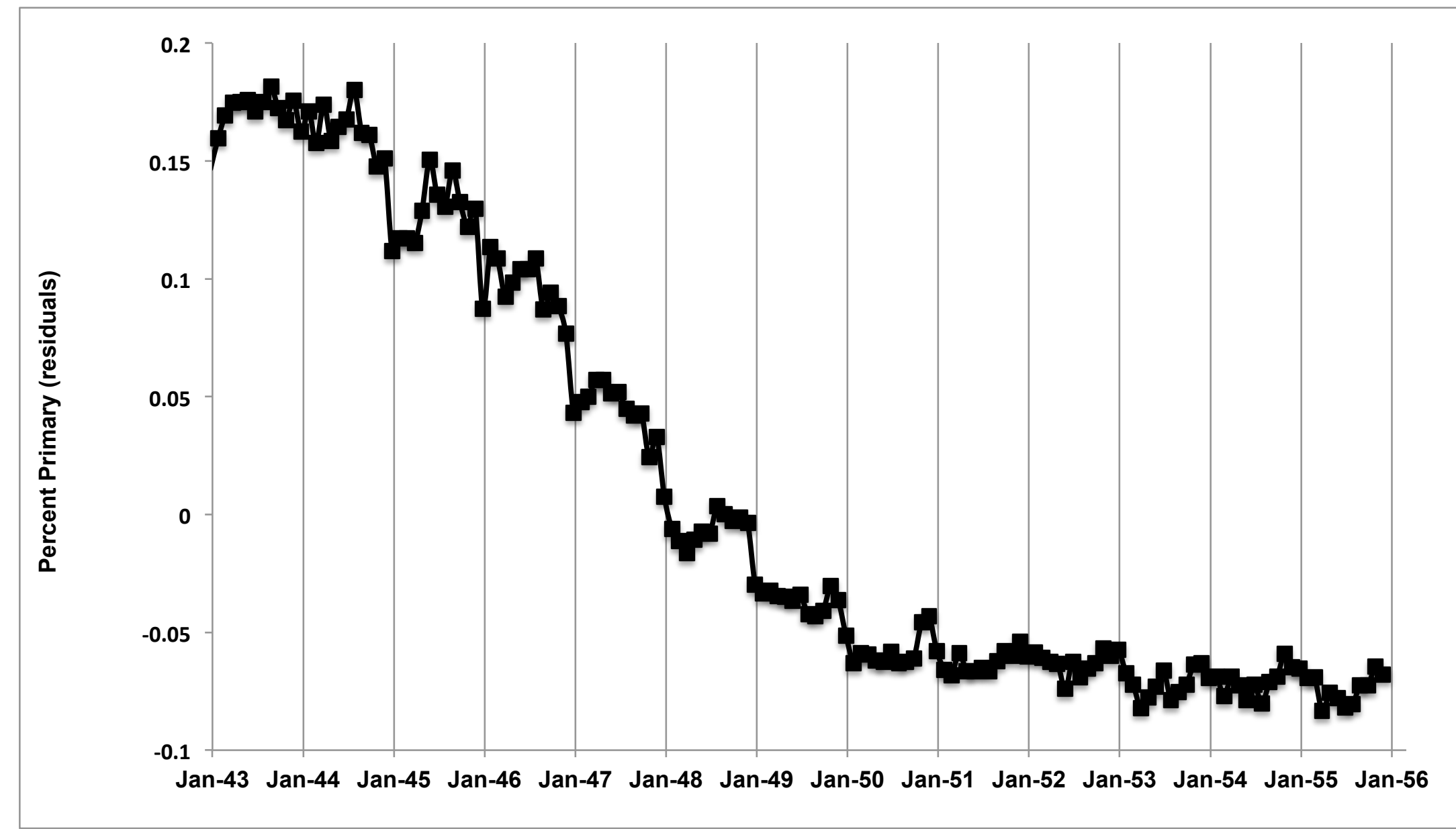

FIGURE 3:Effect of educational expansion for cohorts born 1943-1955 by month of birth

Notes: This figure plot the percent of individuals born between 1943 and 1955 who completed primary education by their month of birth, which are based on residuals. Source: 1992 Romanian Census (PAU sample) 

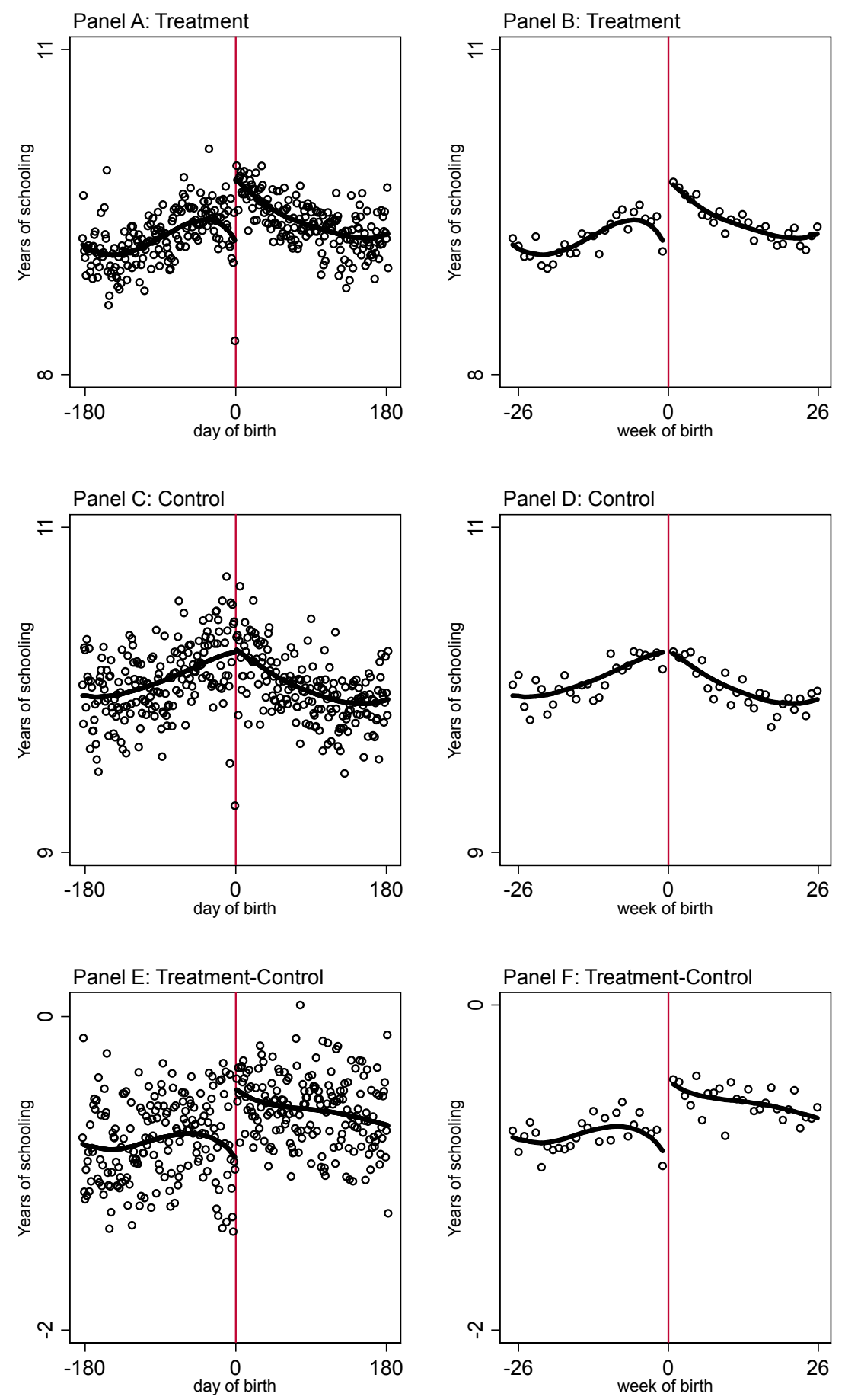

\section{FIGURE 4: Years of Schooling}

Notes: Panels A and B are restricted to individuals born in the treatment years (1944-1950). Panels C and D are restricted to individuals born in the control years (1950-1953). Panels $\mathrm{E}$ and $\mathrm{F}$ are restricted to individuals born in both treatment and control years (1944-1953). The open circles indicate the mean of the outcome by day of birth (panels A, $\mathrm{C}$ and $\mathrm{E}$ ) or week of birth (panels B, D and F). The solid lines are fitted values of residuals from local linear regressions of the dependent variable. Source: 1992 Romanian Census (PAU sample). 

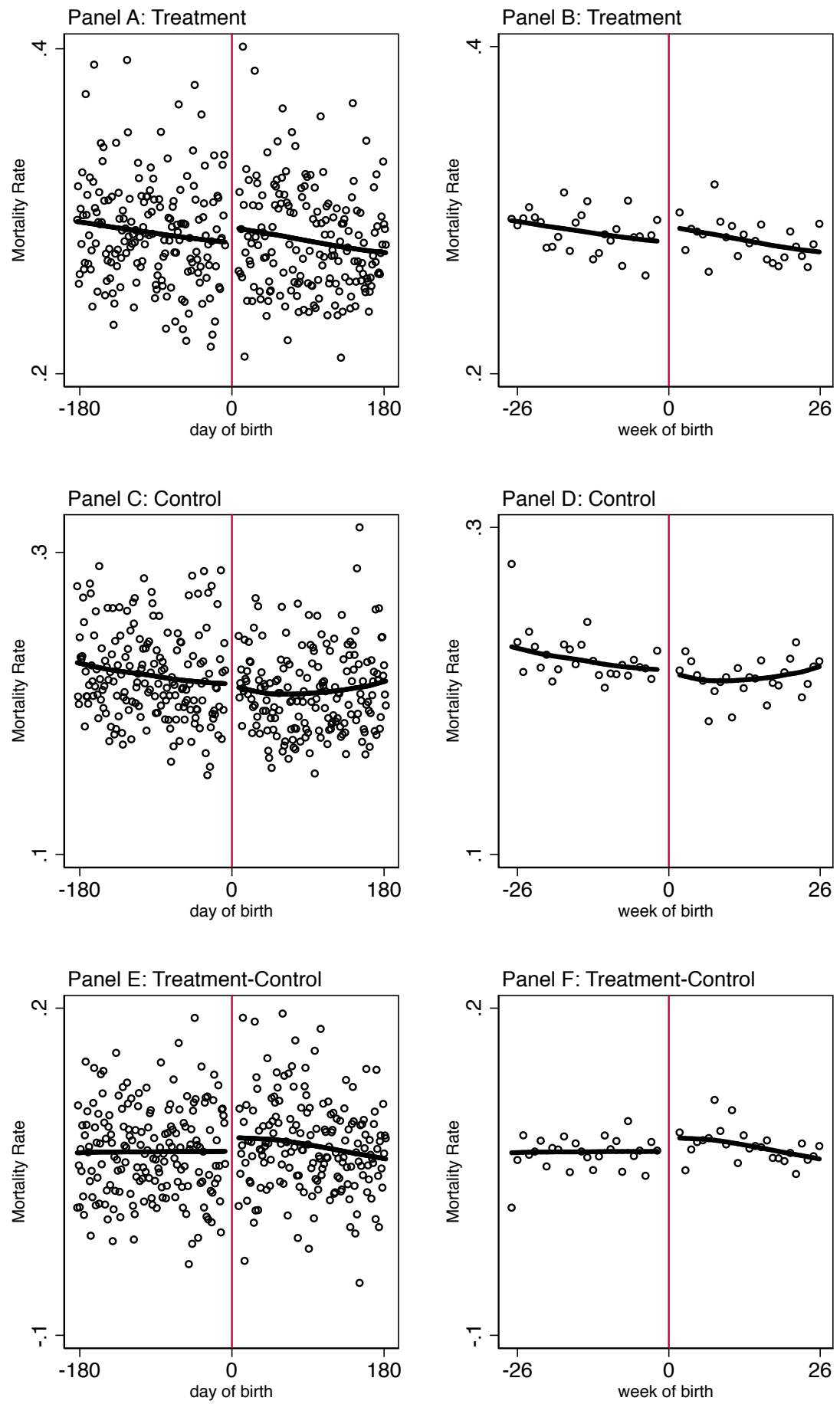

\section{FIGURE 5: Mortality Rate}

Notes: Panels A and B are restricted to individuals born in the treatment years (1944-1950). Panels C and D are restricted to individuals born in the control years (1950-1953). Panels E and F are restricted to individuals born in both treatment and control years (1944-1953). The open circles indicate the mean of the outcome by day of birth (panels A, $\mathrm{C}$ and $\mathrm{E}$ ) or week of birth (panels B, D and F). The solid lines are fitted values of residuals from local linear regressions of the dependent variable. Source: 1994-2011 Vital Statistics Mortality files 


\begin{tabular}{lccr}
\hline \hline & Mean & S.D. & Obs \\
\cline { 2 - 4 } Panel A: Census data & & & \\
Female & 0.506 & 0.500 & 375,103 \\
Age & 42.224 & 2.575 & 375,103 \\
Ethnicity & & & \\
$\quad$ Romanian & 0.893 & 0.309 & 375,103 \\
$\quad$ Hugarian & 0.073 & 0.261 & 375,103 \\
$\quad$ Roma & 0.015 & 0.122 & 375,103 \\
Other & 0.018 & 0.134 & 375,103 \\
Years of schooling & 9.578 & 3.660 & 373,980 \\
Self-reported health index (2011) & 0.076 & 0.265 & $2,058,787$ \\
& & & \\
Panel B: Mortality data & & & 3,284 \\
Overall mortality & 0.260 & 0.081 & \\
Mortality by category & & & 3,284 \\
Cancer & 0.077 & 0.026 & 3,284 \\
Circulatory & 0.105 & 0.039 & 3,284 \\
Preventable & 0.059 & 0.018 & 3,284 \\
Treatable & 0.039 & 0.014 & \\
\hline \hline
\end{tabular}

Source: 1992 Romanian Census (PAU sample) \& Romania VSM files 
Table 2: Effects of the Educational Expansion on Years of Schooling

\begin{tabular}{|c|c|c|c|c|c|c|c|c|c|c|c|c|}
\hline \multirow{3}{*}{ Bandwidth (days) } & \multicolumn{6}{|c|}{ Full sample } & \multicolumn{6}{|c|}{ Excluding 7 days on each side of cutoff } \\
\hline & 180 & 120 & 90 & 60 & 30 & IK & 180 & 120 & 90 & 60 & 30 & IK \\
\hline & $(1)$ & $(2)$ & $(3)$ & $(4)$ & $(5)$ & $(6)$ & $(7)$ & $(8)$ & $(9)$ & $(10)$ & $(11)$ & $(12)$ \\
\hline \multicolumn{13}{|c|}{ Panel A: Treated years } \\
\hline After & $\begin{array}{c}0.209 * * * \\
{[0.048]}\end{array}$ & $\begin{array}{c}0.299 * * * \\
{[0.058]}\end{array}$ & $\begin{array}{c}0.395 * * * \\
{[0.067]}\end{array}$ & $\begin{array}{c}0.517 * * * \\
{[0.082]}\end{array}$ & $\begin{array}{c}0.669 * * * \\
{[0.124]}\end{array}$ & $\begin{array}{c}0.644 * * * \\
{[0.115]}\end{array}$ & $\begin{array}{c}0.104 * * * \\
{[0.039]}\end{array}$ & $\begin{array}{c}0.160 * * * \\
{[0.049]}\end{array}$ & $\begin{array}{c}0.242 * * * \\
{[0.059]}\end{array}$ & $\begin{array}{c}0.336^{* * * *} \\
{[0.077]}\end{array}$ & $\begin{array}{c}0.329 * * \\
{[0.125]}\end{array}$ & $\begin{array}{c}0.344 * * * \\
{[0.082]}\end{array}$ \\
\hline Sample size & 232,899 & 150,135 & 108,458 & 68,527 & 32,013 & 36,820 & 224,186 & 141,422 & 99,745 & 59,814 & 23,300 & 53,167 \\
\hline R-squared & 0.020 & 0.019 & 0.019 & 0.018 & 0.018 & 0.018 & 0.020 & 0.019 & 0.019 & 0.018 & 0.016 & 0.017 \\
\hline \multicolumn{13}{|c|}{ Panel B: Control years } \\
\hline After & $\begin{array}{l}-0.025 \\
{[0.049]}\end{array}$ & $\begin{array}{c}-0.005 \\
{[0.064]}\end{array}$ & $\begin{array}{c}0.030 \\
{[0.078]}\end{array}$ & $\begin{array}{c}0.062 \\
{[0.102]}\end{array}$ & $\begin{array}{c}0.079 \\
{[0.156]}\end{array}$ & $\begin{array}{c}0.073 \\
{[0.146]}\end{array}$ & $\begin{array}{c}-0.056 \\
{[0.045]}\end{array}$ & $\begin{array}{c}-0.042 \\
{[0.060]}\end{array}$ & $\begin{array}{c}-0.004 \\
{[0.074]}\end{array}$ & $\begin{array}{c}0.023 \\
{[0.100]}\end{array}$ & $\begin{array}{c}-0.094 \\
{[0.172]}\end{array}$ & $\begin{array}{c}0.016 \\
{[0.108]}\end{array}$ \\
\hline Sample size & 135,114 & 89,330 & 65,606 & 41,882 & 19,599 & 22,519 & 130,133 & 84,349 & 60,625 & 36,901 & 14,618 & 32,849 \\
\hline R-squared & 0.001 & 0.001 & 0.001 & 0.000 & 0.000 & 0.000 & 0.001 & 0.001 & 0.000 & 0.000 & 0.000 & 0.000 \\
\hline \multicolumn{13}{|l|}{ Panel C: All years } \\
\hline After & $\begin{array}{c}-0.025 \\
{[0.049]}\end{array}$ & $\begin{array}{c}-0.005 \\
{[0.064]}\end{array}$ & $\begin{array}{c}0.030 \\
{[0.078]}\end{array}$ & $\begin{array}{c}0.062 \\
{[0.102]}\end{array}$ & $\begin{array}{c}0.079 \\
{[0.156]}\end{array}$ & $\begin{array}{c}0.073 \\
{[0.146]}\end{array}$ & $\begin{array}{c}-0.056 \\
{[0.045]}\end{array}$ & $\begin{array}{c}-0.042 \\
{[0.060]}\end{array}$ & $\begin{array}{c}-0.004 \\
{[0.074]}\end{array}$ & $\begin{array}{c}0.023 \\
{[0.100]}\end{array}$ & $\begin{array}{c}-0.094 \\
{[0.172]}\end{array}$ & $\begin{array}{c}0.016 \\
{[0.108]}\end{array}$ \\
\hline After*Treatment & $\begin{array}{c}0.234^{* * *} \\
{[0.056]}\end{array}$ & $\begin{array}{c}0.304 * * * \\
{[0.072]}\end{array}$ & $\begin{array}{c}0.365^{* * *} \\
{[0.085]}\end{array}$ & $\begin{array}{c}0.455^{* * *} \\
{[0.103]}\end{array}$ & $\begin{array}{c}0.590 * * * \\
{[0.126]}\end{array}$ & $\begin{array}{c}0.572 * * * \\
{[0.122]}\end{array}$ & $\begin{array}{c}0.160 * * * \\
{[0.057]}\end{array}$ & $\begin{array}{c}0.202 * * * \\
{[0.077]}\end{array}$ & $\begin{array}{c}0.246^{* *} \\
{[0.096]}\end{array}$ & $\begin{array}{c}0.313 * * \\
{[0.129]}\end{array}$ & $\begin{array}{l}0.423 * \\
{[0.214]}\end{array}$ & $\begin{array}{c}0.328 * * \\
{[0.139]}\end{array}$ \\
\hline Sample size & 368,013 & 239,465 & 174,064 & 110,409 & 51,612 & 59,339 & 354,319 & 225,771 & 160,370 & 96,715 & 37,918 & 86,016 \\
\hline R-squared & 0.022 & 0.021 & 0.020 & 0.019 & 0.018 & 0.018 & 0.022 & 0.021 & 0.020 & 0.019 & 0.018 & 0.019 \\
\hline
\end{tabular}

Notes: Heteroskedacticity-robust standard errors clustered by day of birth are in parentheses. $* * *, * *$, and * indicate statistical significance at the 1,5 , and 10 percent

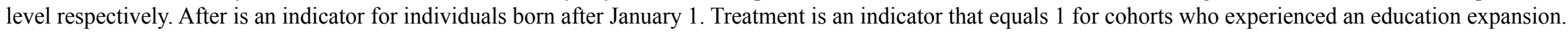
The IK bandwidth is the Imbens and Kalyanarman (2012) optimal bandwidth. 
Table 3: Effects of Educational Expansion on Mortality Rate

\begin{tabular}{|c|c|c|c|c|c|c|c|c|c|c|c|c|}
\hline \multirow[b]{2}{*}{ Bandwidth (days) } & \multicolumn{6}{|c|}{ Full sample } & \multicolumn{6}{|c|}{ Excluding 7 days on each side of cutoff } \\
\hline & $\begin{array}{l}180 \\
(1)\end{array}$ & $\begin{array}{l}120 \\
(2)\end{array}$ & $\begin{array}{l}90 \\
(3)\end{array}$ & $\begin{array}{l}60 \\
(4)\end{array}$ & $\begin{array}{l}30 \\
(5)\end{array}$ & $\begin{array}{l}\text { IK } \\
(6)\end{array}$ & $\begin{array}{l}180 \\
(7)\end{array}$ & $\begin{array}{l}120 \\
(8)\end{array}$ & $\begin{array}{l}90 \\
(9)\end{array}$ & $\begin{array}{c}60 \\
(10)\end{array}$ & $\begin{array}{c}30 \\
(11)\end{array}$ & $\begin{array}{c}\text { IK } \\
(12)\end{array}$ \\
\hline \multicolumn{13}{|c|}{ Panel A: Treated years } \\
\hline After & $\begin{array}{c}0.010 \\
{[0.009]}\end{array}$ & $\begin{array}{c}0.006 \\
{[0.011]}\end{array}$ & $\begin{array}{c}0.003 \\
{[0.013]}\end{array}$ & $\begin{array}{c}0.003 \\
{[0.015]}\end{array}$ & $\begin{array}{c}-0.006 \\
{[0.016]}\end{array}$ & $\begin{array}{c}0.003 \\
{[0.012]}\end{array}$ & $\begin{array}{c}0.011 \\
{[0.010]}\end{array}$ & $\begin{array}{c}0.007 \\
{[0.014]}\end{array}$ & $\begin{array}{c}0.003 \\
{[0.018]}\end{array}$ & $\begin{array}{c}0.004 \\
{[0.026]}\end{array}$ & $\begin{array}{c}-0.016 \\
{[0.053]}\end{array}$ & $\begin{array}{c}0.011 \\
{[0.010]}\end{array}$ \\
\hline Sample size & 2,154 & 1,434 & 1,074 & 714 & 354 & 1,152 & 2,070 & 1,350 & 990 & 630 & 270 & 2,105 \\
\hline R-squared & 0.118 & 0.112 & 0.105 & 0.108 & 0.130 & 0.106 & 0.124 & 0.119 & 0.113 & 0.118 & 0.147 & 0.124 \\
\hline \multicolumn{13}{|c|}{ Panel B: Control years } \\
\hline After & $\begin{array}{c}-0.011 \\
{[0.007]}\end{array}$ & $\begin{array}{c}-0.012 \\
{[0.008]}\end{array}$ & $\begin{array}{c}-0.015 \\
{[0.009]}\end{array}$ & $\begin{array}{c}-0.020 * \\
{[0.011]}\end{array}$ & $\begin{array}{c}-0.046^{* * *} \\
{[0.015]}\end{array}$ & $\begin{array}{c}-0.014 \\
{[0.009]}\end{array}$ & $\begin{array}{c}-0.002 \\
{[0.007]}\end{array}$ & $\begin{array}{c}0.004 \\
{[0.009]}\end{array}$ & $\begin{array}{c}0.006 \\
{[0.010]}\end{array}$ & $\begin{array}{c}0.013 \\
{[0.012]}\end{array}$ & $\begin{array}{c}-0.001 \\
{[0.022]}\end{array}$ & $\begin{array}{c}-0.002 \\
{[0.007]}\end{array}$ \\
\hline Sample size & 1,077 & 717 & 537 & 357 & 177 & 576 & 1,035 & 675 & 495 & 315 & 135 & 1,053 \\
\hline R-squared & 0.071 & 0.073 & 0.079 & 0.082 & 0.146 & 0.078 & 0.058 & 0.055 & 0.055 & 0.046 & 0.042 & 0.059 \\
\hline \multicolumn{13}{|l|}{ Panel C: All years } \\
\hline After & $\begin{array}{c}-0.011 \\
{[0.007]}\end{array}$ & $\begin{array}{c}-0.012 \\
{[0.008]}\end{array}$ & $\begin{array}{c}-0.015 \\
{[0.009]}\end{array}$ & $\begin{array}{c}-0.020 * \\
{[0.011]}\end{array}$ & $\begin{array}{c}-0.046^{* * *} \\
{[0.015]}\end{array}$ & $\begin{array}{c}-0.014 \\
{[0.009]}\end{array}$ & $\begin{array}{c}-0.002 \\
{[0.007]}\end{array}$ & $\begin{array}{c}0.004 \\
{[0.009]}\end{array}$ & $\begin{array}{c}0.006 \\
{[0.010]}\end{array}$ & $\begin{array}{c}0.013 \\
{[0.012]}\end{array}$ & $\begin{array}{c}-0.001 \\
{[0.022]}\end{array}$ & $\begin{array}{c}-0.002 \\
{[0.007]}\end{array}$ \\
\hline After*Treatment & $\begin{array}{c}0.021 * \\
{[0.012]}\end{array}$ & $\begin{array}{c}0.018 \\
{[0.014]}\end{array}$ & $\begin{array}{c}0.018 \\
{[0.016]}\end{array}$ & $\begin{array}{c}0.023 \\
{[0.019]}\end{array}$ & $\begin{array}{l}0.040 * \\
{[0.020]}\end{array}$ & $\begin{array}{c}0.017 \\
{[0.016]}\end{array}$ & $\begin{array}{c}0.013 \\
{[0.014]}\end{array}$ & $\begin{array}{c}0.003 \\
{[0.018]}\end{array}$ & $\begin{array}{c}-0.003 \\
{[0.023]}\end{array}$ & $\begin{array}{c}-0.009 \\
{[0.032]}\end{array}$ & $\begin{array}{c}-0.014 \\
{[0.062]}\end{array}$ & $\begin{array}{c}0.013 \\
{[0.013]}\end{array}$ \\
\hline Sample size & 3,231 & 2,151 & 1,611 & 1,071 & 531 & 1,728 & 3,105 & 2,025 & 1,485 & 945 & 405 & 3,158 \\
\hline R-squared & 0.253 & 0.242 & 0.232 & 0.219 & 0.223 & 0.234 & 0.261 & 0.252 & 0.242 & 0.229 & 0.228 & 0.261 \\
\hline
\end{tabular}

Notes: Heteroskedacticity-robust standard errors clustered by day of birth are in parentheses. ***,**, and * indicate statistical significance at the 1,5 , and 10 percent level respectively. After is an indicator for individuals born after January 1. Treatment is an indicator that equals 1 for cohorts who experienced an education expansion. The IK bandwidth is the Imbens and Kalyanarman (2012) optimal bandwidth. 


\begin{tabular}{|c|c|c|c|c|c|c|c|c|c|c|c|c|}
\hline \multirow{3}{*}{ Bandwidth (days) } & \multicolumn{6}{|c|}{ Full sample } & \multicolumn{6}{|c|}{ Excluding 7 days on each side of cutoff } \\
\hline & 180 & 120 & 90 & 60 & 30 & IK & 180 & 120 & 90 & 60 & 30 & IK \\
\hline & (1) & (2) & (3) & (4) & (5) & (6) & (7) & (8) & (9) & (10) & (11) & (12) \\
\hline \multicolumn{13}{|c|}{ Panel A: Treated years } \\
\hline After & $\begin{array}{c}0.001 \\
{[0.003]}\end{array}$ & $\begin{array}{c}0.001 \\
{[0.004]}\end{array}$ & $\begin{array}{c}-0.000 \\
{[0.005]}\end{array}$ & $\begin{array}{c}-0.001 \\
{[0.005]}\end{array}$ & $\begin{array}{c}-0.003 \\
{[0.005]}\end{array}$ & $\begin{array}{c}0.000 \\
{[0.004]}\end{array}$ & $\begin{array}{c}0.001 \\
{[0.004]}\end{array}$ & $\begin{array}{c}-0.000 \\
{[0.005]}\end{array}$ & $\begin{array}{c}-0.001 \\
{[0.007]}\end{array}$ & $\begin{array}{c}-0.002 \\
{[0.010]}\end{array}$ & $\begin{array}{c}-0.012 \\
{[0.019]}\end{array}$ & $\begin{array}{c}0.001 \\
{[0.004]}\end{array}$ \\
\hline Sample size & 2,154 & 1,434 & 1,074 & 714 & 354 & 1,248 & 2,070 & 1,350 & 990 & 630 & 270 & 2,105 \\
\hline R-squared & 0.062 & 0.058 & 0.055 & 0.063 & 0.098 & 0.056 & 0.067 & 0.063 & 0.060 & 0.066 & 0.094 & 0.067 \\
\hline \multicolumn{13}{|c|}{ Panel B: Control years } \\
\hline After & $\begin{array}{c}-0.003 \\
{[0.002]}\end{array}$ & $\begin{array}{c}-0.002 \\
{[0.003]}\end{array}$ & $\begin{array}{c}-0.003 \\
{[0.004]}\end{array}$ & $\begin{array}{c}-0.004 \\
{[0.004]}\end{array}$ & $\begin{array}{c}-0.014^{* *} \\
{[0.006]}\end{array}$ & $\begin{array}{c}-0.002 \\
{[0.003]}\end{array}$ & $\begin{array}{c}0.001 \\
{[0.003]}\end{array}$ & $\begin{array}{c}0.003 \\
{[0.003]}\end{array}$ & $\begin{array}{c}0.004 \\
{[0.004]}\end{array}$ & $\begin{array}{c}0.008 \\
{[0.005]}\end{array}$ & $\begin{array}{c}-0.000 \\
{[0.009]}\end{array}$ & $\begin{array}{c}0.000 \\
{[0.002]}\end{array}$ \\
\hline Sample size & 1,077 & 717 & 537 & 357 & 177 & 624 & 1,035 & 675 & 495 & 315 & 135 & 1,053 \\
\hline R-squared & 0.049 & 0.047 & 0.049 & 0.049 & 0.104 & 0.048 & 0.039 & 0.036 & 0.035 & 0.028 & 0.022 & 0.040 \\
\hline \multicolumn{13}{|l|}{ Panel C: All years } \\
\hline After & $\begin{array}{l}-0.003 \\
{[0.002]}\end{array}$ & $\begin{array}{c}-0.002 \\
{[0.003]}\end{array}$ & $\begin{array}{c}-0.003 \\
{[0.004]}\end{array}$ & $\begin{array}{c}-0.004 \\
{[0.004]}\end{array}$ & $\begin{array}{c}-0.014 * * \\
{[0.006]}\end{array}$ & $\begin{array}{c}-0.002 \\
{[0.003]}\end{array}$ & $\begin{array}{c}0.001 \\
{[0.003]}\end{array}$ & $\begin{array}{c}0.003 \\
{[0.003]}\end{array}$ & $\begin{array}{c}0.004 \\
{[0.004]}\end{array}$ & $\begin{array}{c}0.008 \\
{[0.005]}\end{array}$ & $\begin{array}{c}-0.000 \\
{[0.009]}\end{array}$ & $\begin{array}{c}0.000 \\
{[0.002]}\end{array}$ \\
\hline After*Treatment & $\begin{array}{c}0.004 \\
{[0.004]}\end{array}$ & $\begin{array}{c}0.003 \\
{[0.006]}\end{array}$ & $\begin{array}{c}0.003 \\
{[0.006]}\end{array}$ & $\begin{array}{c}0.004 \\
{[0.008]}\end{array}$ & $\begin{array}{c}0.011 \\
{[0.008]}\end{array}$ & $\begin{array}{c}0.003 \\
{[0.006]}\end{array}$ & $\begin{array}{c}0.000 \\
{[0.005]}\end{array}$ & $\begin{array}{c}-0.003 \\
{[0.007]}\end{array}$ & $\begin{array}{c}-0.006 \\
{[0.009]}\end{array}$ & $\begin{array}{c}-0.010 \\
{[0.013]}\end{array}$ & $\begin{array}{c}-0.012 \\
{[0.024]}\end{array}$ & $\begin{array}{c}0.001 \\
{[0.005]}\end{array}$ \\
\hline Sample size & 3,231 & 2,151 & 1,611 & 1,071 & 531 & 1,872 & 3,105 & 2,025 & 1,485 & 945 & 405 & 3,158 \\
\hline R-squared & 0.167 & 0.160 & 0.153 & 0.145 & 0.163 & 0.157 & 0.174 & 0.169 & 0.162 & 0.152 & 0.158 & 0.174 \\
\hline
\end{tabular}

Notes: Heteroskedacticity-robust standard errors clustered by day of birth are in parentheses. $* * *, * *$, and * indicate statistical significance at the 1,5 , and 10 percent level respectively. After is an indicator for individuals born after January 1. Treatment is an indicator that equals 1 for cohorts who experienced an education expansion. The IK bandwidth is the Imbens and Kalyanarman (2012) optimal bandwidth. We use the ICD-10 diseases codes - chapter C for cancer. 


\begin{tabular}{|c|c|c|c|c|c|c|c|c|c|c|c|c|}
\hline \multirow{3}{*}{$\begin{array}{l}\text { Bandwidth } \\
\text { (days) }\end{array}$} & \multicolumn{6}{|c|}{ Full sample } & \multicolumn{6}{|c|}{ Excluding 7 days on each side of cutoff } \\
\hline & 180 & 120 & 90 & & & IK & & 120 & & 60 & 30 & IK \\
\hline & $(1)$ & $(2)$ & (3) & (4) & $(5)$ & $(6)$ & (7) & $(8)$ & $(9)$ & $(10)$ & $(11)$ & $(12)$ \\
\hline \multicolumn{13}{|c|}{ Panel A: Treated years } \\
\hline After & $\begin{array}{c}0.007 * * \\
{[0.004]}\end{array}$ & $\begin{array}{c}0.005 \\
{[0.004]}\end{array}$ & $\begin{array}{c}0.003 \\
{[0.005]}\end{array}$ & $\begin{array}{c}0.002 \\
{[0.006]}\end{array}$ & $\begin{array}{c}-0.003 \\
{[0.007]}\end{array}$ & $\begin{array}{c}0.005 \\
{[0.004]}\end{array}$ & $\begin{array}{c}0.009 * * \\
{[0.004]}\end{array}$ & $\begin{array}{c}0.007 \\
{[0.006]}\end{array}$ & $\begin{array}{c}0.005 \\
{[0.007]}\end{array}$ & $\begin{array}{c}0.006 \\
{[0.010]}\end{array}$ & $\begin{array}{c}0.005 \\
{[0.019]}\end{array}$ & $\begin{array}{c}0.009 * * \\
{[0.004]}\end{array}$ \\
\hline Sample size & 2,154 & 1,434 & 1,074 & 714 & 354 & 1,530 & 2,070 & 1,350 & 990 & 630 & 270 & 1,974 \\
\hline R-squared & 0.223 & 0.216 & 0.210 & 0.215 & 0.238 & 0.217 & 0.227 & 0.220 & 0.215 & 0.222 & 0.255 & 0.226 \\
\hline \multicolumn{13}{|c|}{ Panel B: Control years } \\
\hline After & $\begin{array}{c}-0.003 \\
{[0.002]}\end{array}$ & $\begin{array}{c}-0.003 \\
{[0.003]}\end{array}$ & $\begin{array}{c}-0.004 \\
{[0.003]}\end{array}$ & $\begin{array}{c}-0.005 \\
{[0.003]}\end{array}$ & $\begin{array}{c}-0.012 * * * \\
{[0.004]}\end{array}$ & $\begin{array}{c}-0.003 \\
{[0.003]}\end{array}$ & $\begin{array}{c}-0.000 \\
{[0.003]}\end{array}$ & $\begin{array}{c}0.000 \\
{[0.004]}\end{array}$ & $\begin{array}{c}0.001 \\
{[0.004]}\end{array}$ & $\begin{array}{c}0.003 \\
{[0.005]}\end{array}$ & $\begin{array}{c}-0.004 \\
{[0.010]}\end{array}$ & $\begin{array}{c}-0.000 \\
{[0.003]}\end{array}$ \\
\hline Sample size & 1,077 & 717 & 537 & 357 & 177 & 765 & 1,035 & 675 & 495 & 315 & 135 & 987 \\
\hline R-squared & 0.123 & 0.128 & 0.137 & 0.144 & 0.201 & 0.126 & 0.108 & 0.105 & 0.108 & 0.100 & 0.095 & 0.107 \\
\hline \multicolumn{13}{|c|}{ Panel C: All years } \\
\hline After & $\begin{array}{c}-0.003 \\
{[0.002]}\end{array}$ & $\begin{array}{c}-0.003 \\
{[0.003]}\end{array}$ & $\begin{array}{c}-0.004 \\
{[0.003]}\end{array}$ & $\begin{array}{c}-0.005 \\
{[0.003]}\end{array}$ & $\begin{array}{c}-0.012 * * * \\
{[0.004]}\end{array}$ & $\begin{array}{c}-0.003 \\
{[0.003]}\end{array}$ & $\begin{array}{c}-0.000 \\
{[0.003]}\end{array}$ & $\begin{array}{c}0.000 \\
{[0.004]}\end{array}$ & $\begin{array}{c}0.001 \\
{[0.004]}\end{array}$ & $\begin{array}{c}0.003 \\
{[0.005]}\end{array}$ & $\begin{array}{c}-0.004 \\
{[0.010]}\end{array}$ & $\begin{array}{c}-0.000 \\
{[0.003]}\end{array}$ \\
\hline After*Treatment & $\begin{array}{c}0.010 * * \\
{[0.004]}\end{array}$ & $\begin{array}{c}0.008 \\
{[0.005]}\end{array}$ & $\begin{array}{c}0.007 \\
{[0.006]}\end{array}$ & $\begin{array}{c}0.007 \\
{[0.007]}\end{array}$ & $\begin{array}{c}0.009 \\
{[0.007]}\end{array}$ & $\begin{array}{c}0.008 \\
{[0.005]}\end{array}$ & $\begin{array}{c}0.010^{*} \\
{[0.005]}\end{array}$ & $\begin{array}{c}0.006 \\
{[0.007]}\end{array}$ & $\begin{array}{c}0.004 \\
{[0.008]}\end{array}$ & $\begin{array}{c}0.004 \\
{[0.011]}\end{array}$ & $\begin{array}{c}0.009 \\
{[0.020]}\end{array}$ & $\begin{array}{c}0.009 * \\
{[0.005]}\end{array}$ \\
\hline Sample size & 3,231 & 2,151 & 1,611 & 1,071 & 531 & 2,295 & 3,105 & 2,025 & 1,485 & 945 & 405 & 2,961 \\
\hline R-squared & 0.410 & 0.399 & 0.391 & 0.383 & 0.388 & 0.401 & 0.413 & 0.402 & 0.393 & 0.382 & 0.380 & 0.412 \\
\hline
\end{tabular}

Notes: Heteroskedacticity-robust standard errors clustered by day of birth are in parentheses. ***,**, and * indicate statistical significance at the 1,5 , and 10 percent

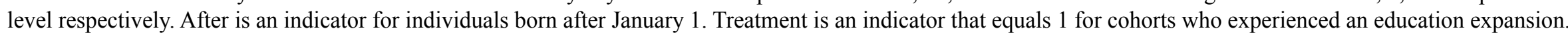
The IK bandwidth is the Imbens and Kalyanarman (2012) optimal bandwidth. We use the ICD-10 diseases codes- chapter I for the circulatory diseases. 
Notes: Heteroskedacticity-robust standard errors clustered by day of birth are in parentheses. $* * * * *$, and * indicate statistical significance at the 1,5 , and 10 percent

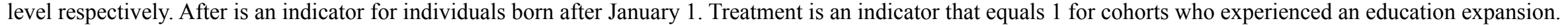
The IK bandwidth is the Imbens and Kalyanarman (2012) optimal bandwidth. 
Table 7: Effect of Educational Expansion on Employment

\begin{tabular}{|c|c|c|c|c|c|c|c|c|c|c|c|c|}
\hline \multirow{3}{*}{ Bandwidth (days) } & \multicolumn{6}{|c|}{ Full sample } & \multicolumn{6}{|c|}{ Excluding 7 days on each side of cutoff } \\
\hline & 180 & 120 & 90 & 60 & 30 & IK & 180 & 120 & 90 & 60 & 30 & $\mathrm{IK}$ \\
\hline & $(1)$ & $(2)$ & (3) & (4) & $(5)$ & $(6)$ & $(7)$ & $(8)$ & $(9)$ & $(10)$ & $(11)$ & $(12)$ \\
\hline \multicolumn{13}{|c|}{ Panel A: Treated years } \\
\hline After & $\begin{array}{c}0.010 * * * \\
{[0.004]}\end{array}$ & $\begin{array}{c}0.017 * * * \\
{[0.004]}\end{array}$ & $\begin{array}{c}0.021 * * * \\
{[0.005]}\end{array}$ & $\begin{array}{c}0.027 * * * \\
{[0.005]}\end{array}$ & $\begin{array}{c}0.037 * * * \\
{[0.007]}\end{array}$ & $\begin{array}{c}0.034 * * * \\
{[0.007]}\end{array}$ & $\begin{array}{c}0.003 \\
{[0.003]}\end{array}$ & $\begin{array}{c}0.008 * \\
{[0.004]}\end{array}$ & $\begin{array}{c}0.010^{*} \\
{[0.005]}\end{array}$ & $\begin{array}{c}0.015^{* *} \\
{[0.007]}\end{array}$ & $\begin{array}{c}0.023 \\
{[0.015]}\end{array}$ & $\begin{array}{c}0.008 * \\
{[0.004]}\end{array}$ \\
\hline Sample size & 233,402 & 150,439 & 108,658 & 68,721 & 32,116 & 40,385 & 224,659 & 141,696 & 99,915 & 59,978 & 23,373 & 143,836 \\
\hline R-squared & 0.002 & 0.002 & 0.002 & 0.002 & 0.003 & 0.003 & 0.002 & 0.002 & 0.002 & 0.002 & 0.002 & 0.002 \\
\hline \multicolumn{13}{|c|}{ Panel B: Control years } \\
\hline After & $\begin{array}{c}-0.005 \\
{[0.005]}\end{array}$ & $\begin{array}{c}0.001 \\
{[0.006]}\end{array}$ & $\begin{array}{c}0.007 \\
{[0.006]}\end{array}$ & $\begin{array}{c}0.011 \\
{[0.008]}\end{array}$ & $\begin{array}{c}0.022 * * \\
{[0.010]}\end{array}$ & $\begin{array}{c}0.022 * * \\
{[0.009]}\end{array}$ & $\begin{array}{c}-0.009 * \\
{[0.005]}\end{array}$ & $\begin{array}{c}-0.005 \\
{[0.007]}\end{array}$ & $\begin{array}{c}0.001 \\
{[0.008]}\end{array}$ & $\begin{array}{c}0.007 \\
{[0.012]}\end{array}$ & $\begin{array}{c}0.040 * \\
{[0.020]}\end{array}$ & $\begin{array}{c}-0.005 \\
{[0.007]}\end{array}$ \\
\hline Sample size & 135,396 & 89,500 & 65,692 & 42,013 & 19,661 & 24,801 & 130,393 & 84,497 & 60,689 & 37,010 & 14,658 & 85,598 \\
\hline R-squared & 0.000 & 0.000 & 0.000 & 0.000 & 0.000 & 0.000 & 0.000 & 0.000 & 0.000 & 0.000 & 0.001 & 0.000 \\
\hline \multicolumn{13}{|l|}{ Panel C: All years } \\
\hline After & $\begin{array}{c}-0.005 \\
{[0.005]}\end{array}$ & $\begin{array}{c}0.001 \\
{[0.006]}\end{array}$ & $\begin{array}{c}0.007 \\
{[0.006]}\end{array}$ & $\begin{array}{c}0.011 \\
{[0.008]}\end{array}$ & $\begin{array}{c}0.022 * * \\
{[0.010]}\end{array}$ & $\begin{array}{c}0.022 * * \\
{[0.009]}\end{array}$ & $\begin{array}{c}-0.009 * \\
{[0.005]}\end{array}$ & $\begin{array}{c}-0.005 \\
{[0.007]}\end{array}$ & $\begin{array}{c}0.001 \\
{[0.008]}\end{array}$ & $\begin{array}{c}0.007 \\
{[0.012]}\end{array}$ & $\begin{array}{c}0.040 * \\
{[0.020]}\end{array}$ & $\begin{array}{c}-0.005 \\
{[0.007]}\end{array}$ \\
\hline After*Treatment & $\begin{array}{c}0.015^{* * *} * \\
{[0.005]}\end{array}$ & $\begin{array}{c}0.016^{* *} \\
{[0.007]}\end{array}$ & $\begin{array}{l}0.015^{*} \\
{[0.008]}\end{array}$ & $\begin{array}{c}0.016^{*} \\
{[0.009]}\end{array}$ & $\begin{array}{c}0.015 \\
{[0.012]}\end{array}$ & $\begin{array}{c}0.012 \\
{[0.011]}\end{array}$ & $\begin{array}{c}0.012 * * \\
{[0.006]}\end{array}$ & $\begin{array}{c}0.013 \\
{[0.008]}\end{array}$ & $\begin{array}{c}0.009 \\
{[0.010]}\end{array}$ & $\begin{array}{c}0.008 \\
{[0.014]}\end{array}$ & $\begin{array}{c}-0.017 \\
{[0.026]}\end{array}$ & $\begin{array}{c}0.013 \\
{[0.008]}\end{array}$ \\
\hline Sample size & 368,798 & 239,939 & 174,350 & 110,734 & 51,777 & 65,186 & 355,052 & 226,193 & 160,604 & 96,988 & 38,031 & 229,434 \\
\hline R-squared & 0.002 & 0.002 & 0.002 & 0.002 & 0.003 & 0.002 & 0.002 & 0.002 & 0.002 & 0.002 & 0.002 & 0.002 \\
\hline
\end{tabular}

Notes: Heteroskedacticity-robust standard errors clustered by day of birth are in parentheses. ***, **, and * indicate statistical significance at the 1,5 , and 10 percent level respectively. After is an indicator for individuals born after January 1 . Treatment is an indicator that equals 1 for cohorts who experienced an education expansion. The IK bandwidth is the Imbens and Kalyanarman (2012) optimal bandwidth. 

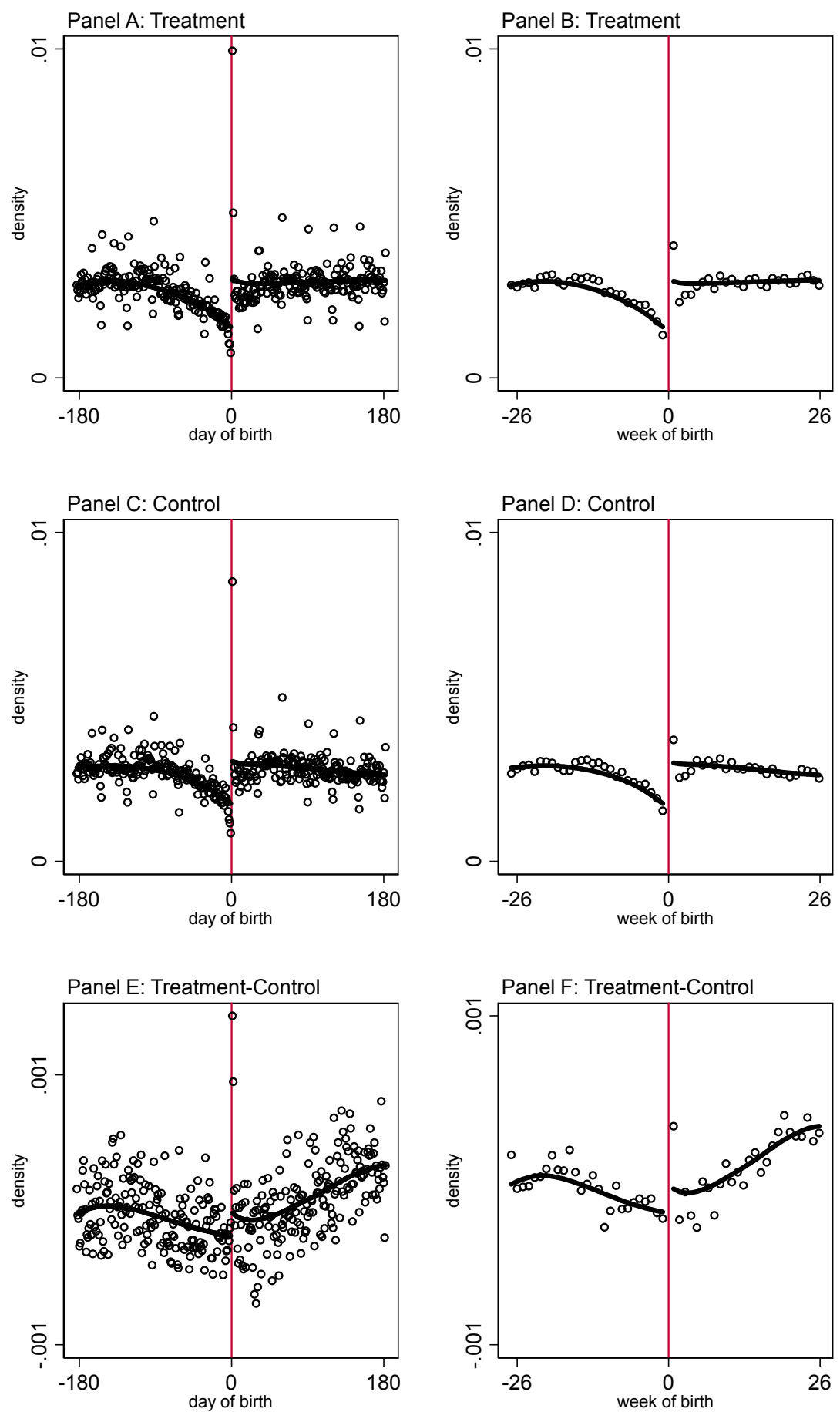

\section{APPENDIX FIGURE 1: Density check}

Notes: Panels A and B are restricted to individuals born in the treatment years (1944-1950). Panels C and D are restricted to individuals born in the control years (1950-1953). Panels E and F are restricted to individuals born in both treatment and control years (1944-1953). The open circles indicate the mean of the outcome by day of birth (panels A, C and E) or week of birth (panels B, D and F). The solid lines are fitted values of residuals from local linear regressions of the dependent variable. Source: 1992 Romanian Census (PAU sample). 

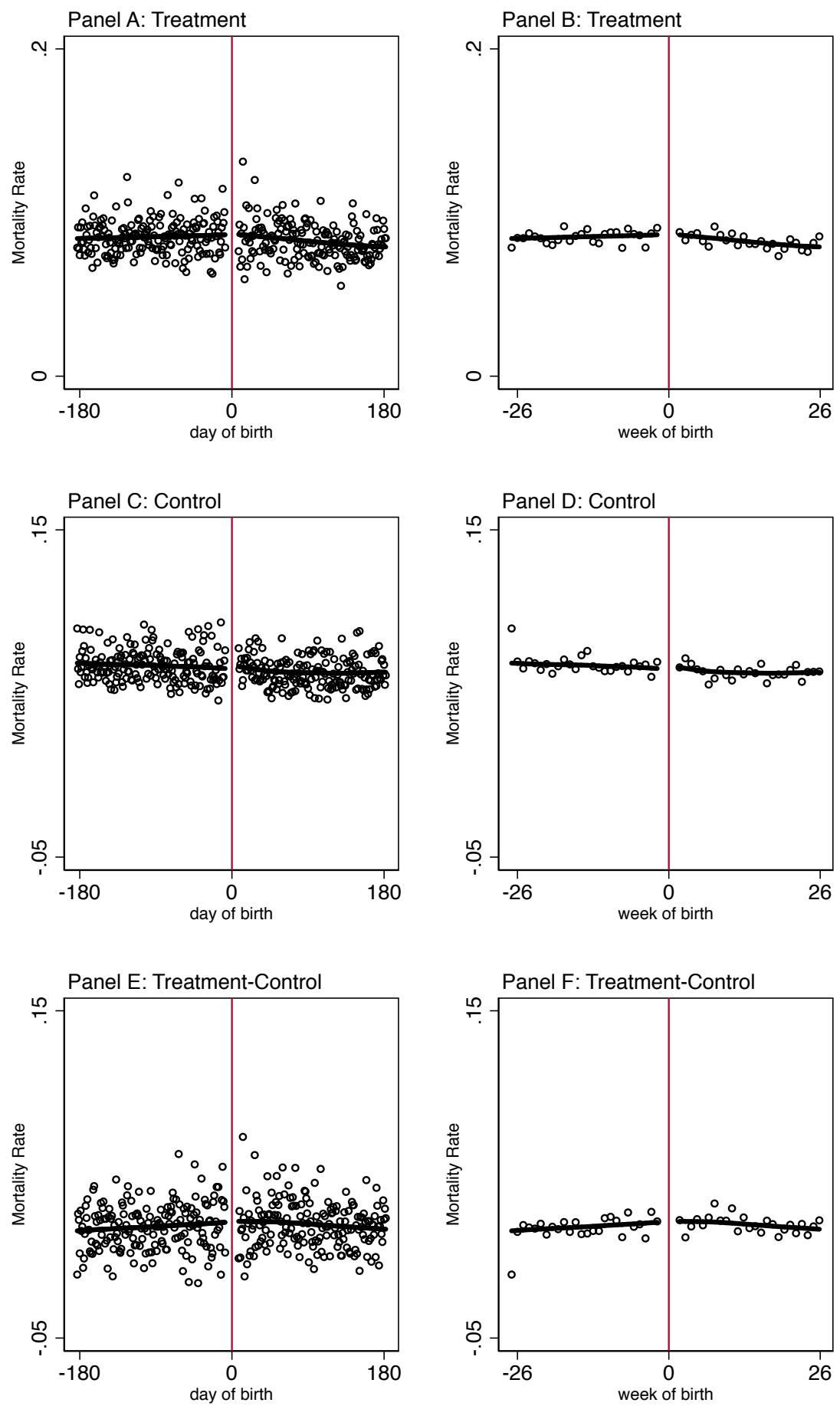

\section{APPENDIX FIGURE 2: Mortality Rate due to Cancer}

Notes: Panels A and B are restricted to individuals born in the treatment years (1944-1950). Panels C and D are restricted to individuals born in the control years (1950-1953). Panels E and F are restricted to individuals born in both treatment and control years (1944-1953). The open circles indicate the mean of the outcome by day of birth (panels A, $\mathrm{C}$ and $\mathrm{E}$ ) or week of birth (panels B, D and F). The solid lines are fitted values of residuals from local linear regressions of the dependent variable. Source: 1994-2011 Vital Statistics Mortality files 

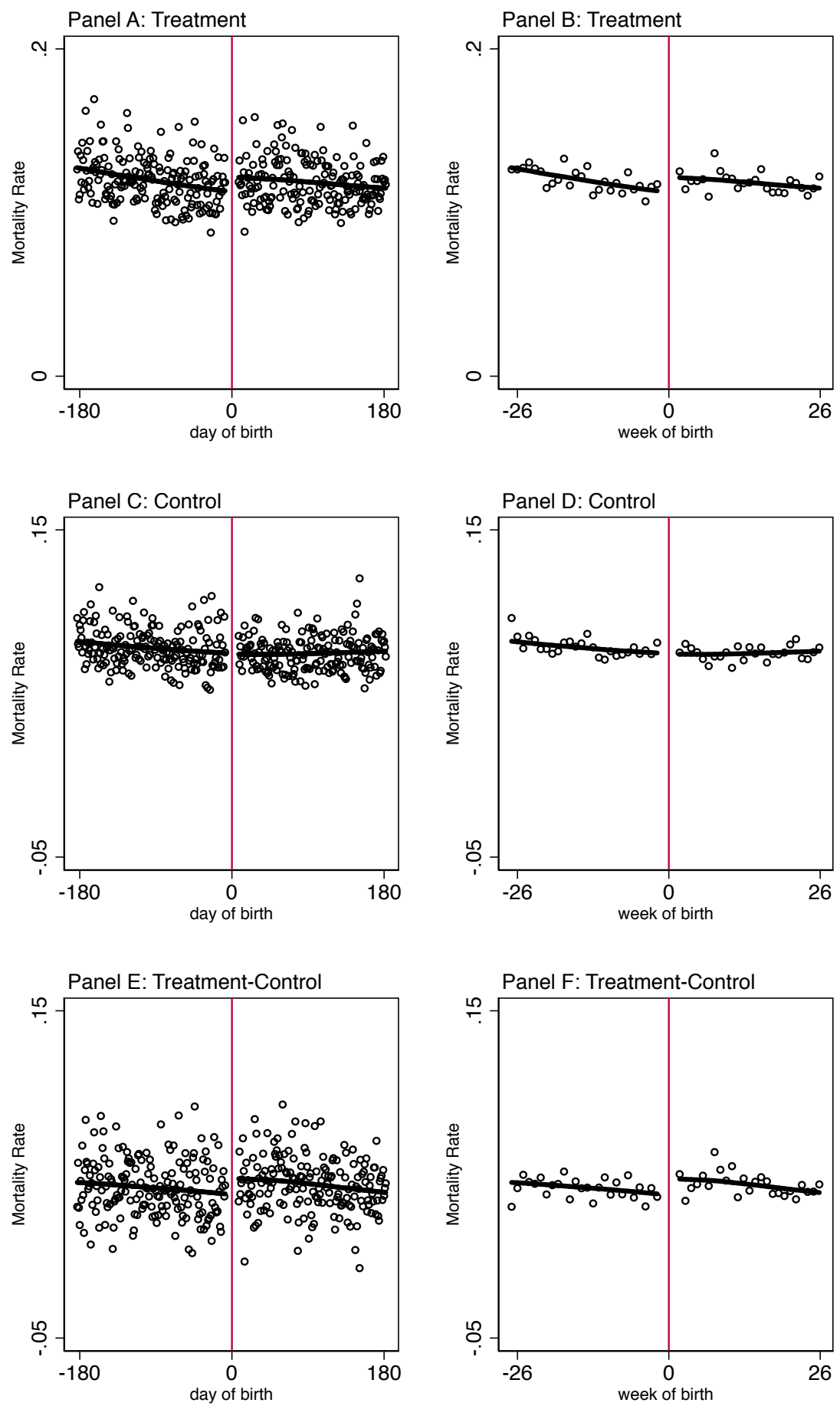

\section{APPENDIX FIGURE 3: Mortality Rate due to Circulatory Diseases}

Notes: Panels A and B are restricted to individuals born in the treatment years (1944-1950). Panels C and D are restricted to individuals born in the control years (1950-1953). Panels E and F are restricted to individuals born in both treatment and control years (1944-1953). The open circles indicate the mean of the outcome by day of birth (panels A, $\mathrm{C}$ and $\mathrm{E}$ ) or week of birth (panels B, D and F). The solid lines are fitted values of residuals from local linear regressions of the dependent variable. Source: 1994-2011 Vital Statistics Mortality files 

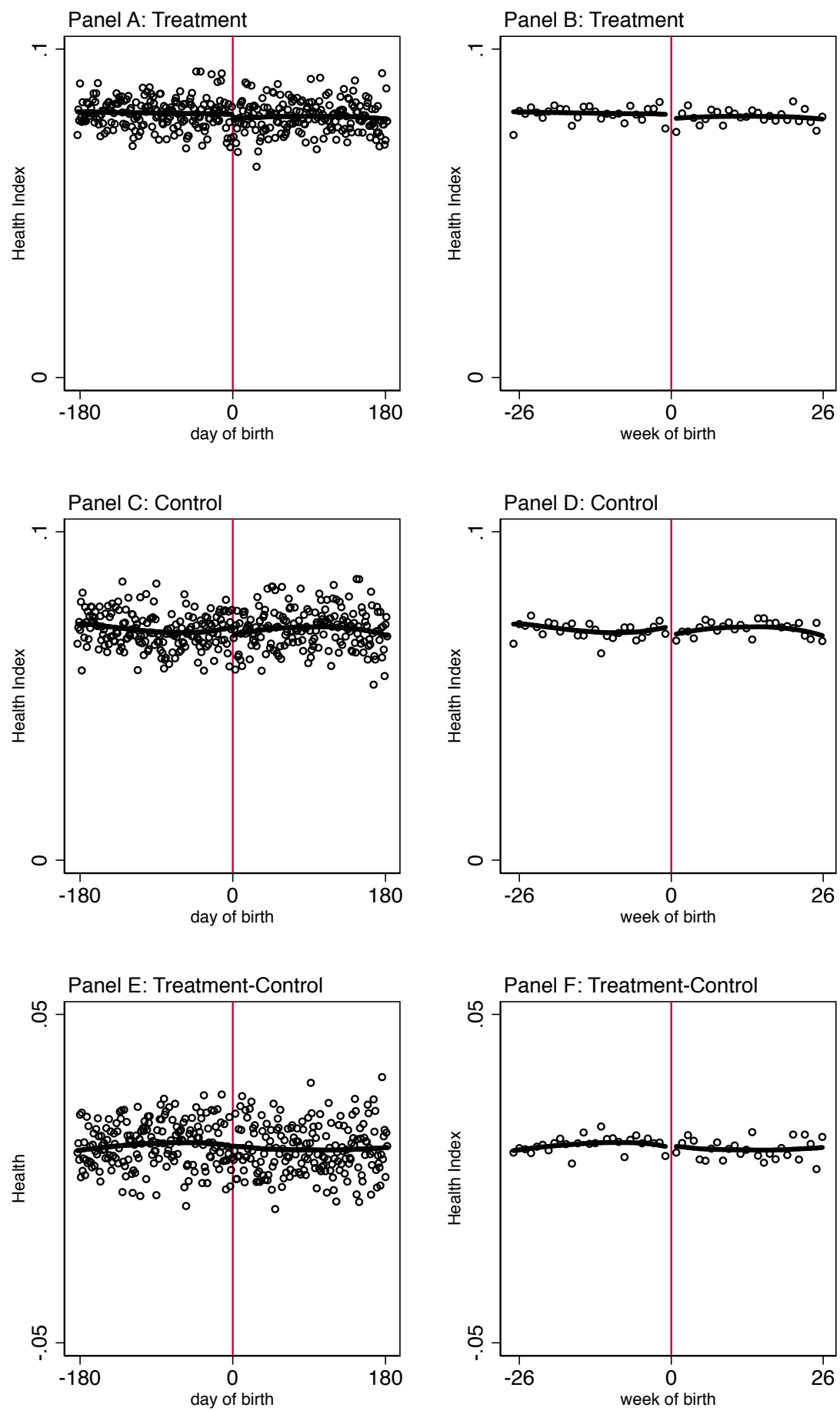

\section{APPENDIX FIGURE 4:Self-Reported Health Index}

Notes: Panels A and B are restricted to individuals born in the treatment years (1944-1950). Panels C and D are restricted to individuals born in the control years (1950-1953). Panels E and F are restricted to individuals born in both treatment and control years (1944-1953). The open circles indicate the mean of the outcome by day of birth (panels A, $\mathrm{C}$ and $\mathrm{E}$ ) or week of birth (panels B, D and F). The solid lines are fitted values of residuals from local linear regressions of the dependent variable. Source: 2011 Romanian Census 

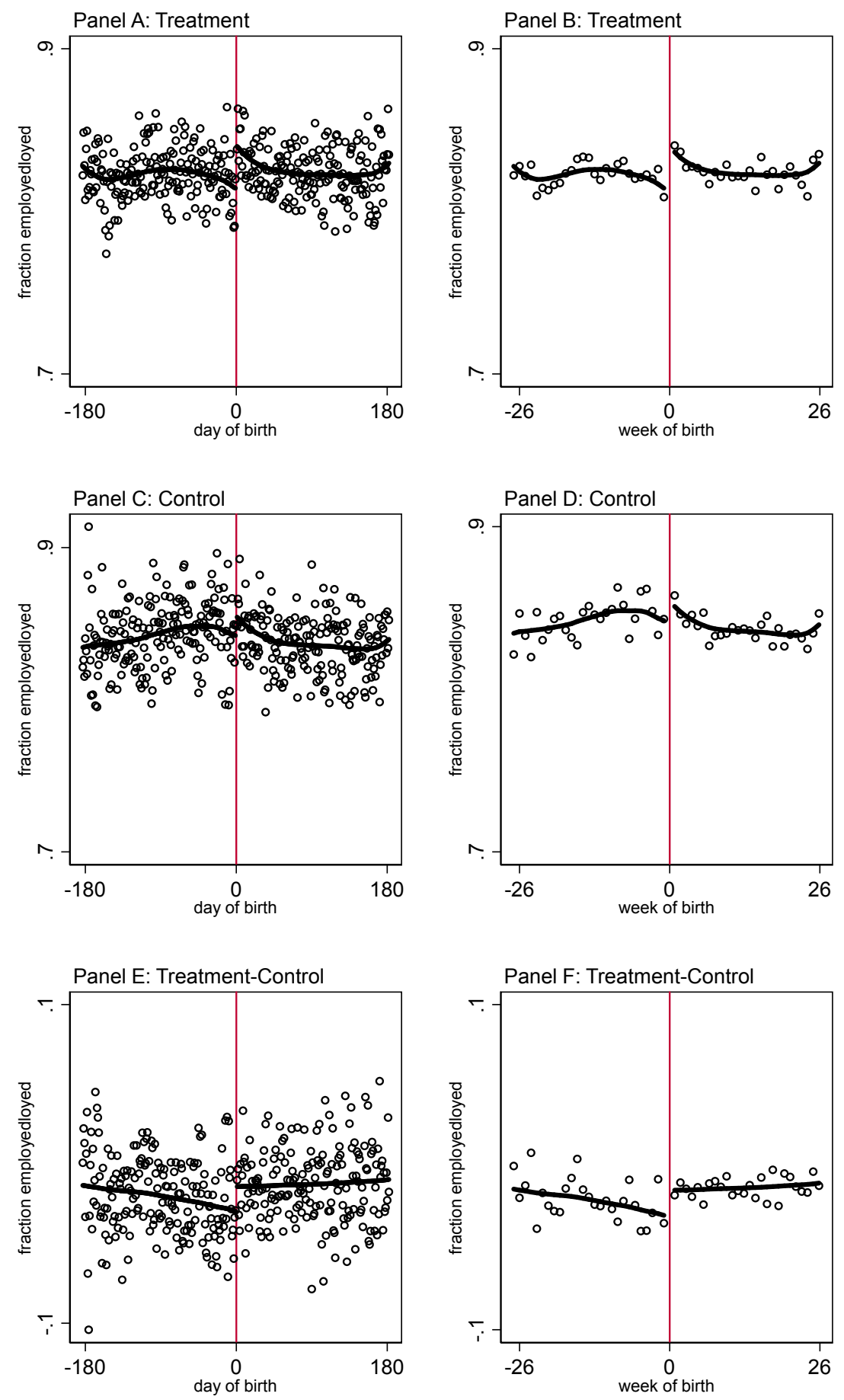

\section{APPENDIX FIGURE 5: Rate of Employment}

Notes: Panels A and B are restricted to individuals born in the treatment years (1944-1950). Panels C and D are restricted to individuals born in the control years (1950-1953). Panels $\mathrm{E}$ and $\mathrm{F}$ are restricted to individuals born in both treatment and control years (1944-1953). The open circles indicate the mean of the outcome by day of birth (panels A, $\mathrm{C}$ and $\mathrm{E}$ ) or week of birth (panels B, D and F). The solid lines are fitted values of residuals from local linear regressions of the dependent variable. Source: 1992 Romanian Census (PAU sample). 


\begin{tabular}{|c|c|c|c|c|c|c|c|c|c|c|c|c|}
\hline \multirow{3}{*}{ Bandwidth (days) } & \multicolumn{6}{|c|}{ Full sample } & \multicolumn{6}{|c|}{ Excluding 7 days on each side of cutoff } \\
\hline & 180 & 120 & 90 & 60 & 30 & IK & 180 & 120 & 90 & 60 & 30 & IK \\
\hline & $(1)$ & $(2)$ & $(3)$ & $(4)$ & $(5)$ & $(6)$ & $(7)$ & $(8)$ & $(9)$ & (10) & (11) & (12) \\
\hline \multicolumn{13}{|c|}{ Panel A: Treated years } \\
\hline After & $\begin{array}{c}0.167 * * \\
{[0.073]}\end{array}$ & $\begin{array}{c}0.224^{* *} \\
{[0.100]}\end{array}$ & $\begin{array}{c}0.262 * * \\
{[0.122]}\end{array}$ & $\begin{array}{c}0.337 * * \\
{[0.150]}\end{array}$ & $\begin{array}{c}0.519 * * * \\
{[0.179]}\end{array}$ & $\begin{array}{c}1.005^{* * * *} \\
{[0.119]}\end{array}$ & $\begin{array}{c}0.064 * * * \\
{[0.011]}\end{array}$ & $\begin{array}{c}0.072 * * * \\
{[0.013]}\end{array}$ & $\begin{array}{c}0.060 * * * \\
{[0.013]}\end{array}$ & $\begin{array}{c}0.049 * * * \\
{[0.011]}\end{array}$ & $\begin{array}{c}0.076^{* * *} \\
{[0.018]}\end{array}$ & - \\
\hline Sample size & 233,596 & 150,586 & 108,797 & 68,738 & 32,116 & 8,743 & 224,853 & 141,843 & 100,054 & 59,995 & 23,373 & - \\
\hline R-squared & 0.139 & 0.188 & 0.227 & 0.305 & 0.502 & 0.843 & 0.210 & 0.284 & 0.312 & 0.352 & 0.473 & - \\
\hline \multicolumn{13}{|c|}{ Panel B: Control years } \\
\hline After & $\begin{array}{c}0.134 * * * \\
{[0.050]}\end{array}$ & $\begin{array}{c}0.174 * * \\
{[0.070]}\end{array}$ & $\begin{array}{c}0.200 * * \\
{[0.088]}\end{array}$ & $\begin{array}{c}0.249 * * \\
{[0.114]}\end{array}$ & $\begin{array}{c}0.388 * * \\
{[0.148]}\end{array}$ & $\begin{array}{c}0.823 * * * \\
{[0.111]}\end{array}$ & $\begin{array}{c}0.069 * * * \\
{[0.010]}\end{array}$ & $\begin{array}{c}0.078 * * * \\
{[0.011]}\end{array}$ & $\begin{array}{c}0.069 * * * \\
{[0.012]}\end{array}$ & $\begin{array}{c}0.055 * * * \\
{[0.012]}\end{array}$ & $\begin{array}{c}0.067 * * \\
{[0.026]}\end{array}$ & - \\
\hline Sample size & 135,524 & 89,614 & 65,819 & 42,014 & 19,661 & 5,003 & 130,521 & 84,611 & 60,816 & 37,011 & 14,658 & - \\
\hline R-squared & 0.157 & 0.199 & 0.223 & 0.280 & 0.455 & 0.828 & 0.172 & 0.286 & 0.337 & 0.405 & 0.446 & - \\
\hline \multicolumn{13}{|l|}{$\overline{\text { Panel C: All years }}$} \\
\hline After & $\begin{array}{c}0.134 * * * \\
{[0.050]}\end{array}$ & $\begin{array}{c}0.174 * * \\
{[0.070]}\end{array}$ & $\begin{array}{c}0.200 * * \\
{[0.088]}\end{array}$ & $\begin{array}{c}0.249 * * \\
{[0.114]}\end{array}$ & $\begin{array}{c}0.388 * * \\
{[0.148]}\end{array}$ & $\begin{array}{c}0.823 * * * \\
{[0.111]}\end{array}$ & $\begin{array}{c}0.069 * * * \\
{[0.010]}\end{array}$ & $\begin{array}{c}0.078 * * * \\
{[0.011]}\end{array}$ & $\begin{array}{c}0.069^{* * *} * \\
{[0.012]}\end{array}$ & $\begin{array}{c}0.055^{* * *} \\
{[0.012]}\end{array}$ & $\begin{array}{c}0.067 * * \\
{[0.026]}\end{array}$ & - \\
\hline After*Treatment & $\begin{array}{c}0.033 \\
{[0.024]}\end{array}$ & $\begin{array}{c}0.050 \\
{[0.030]}\end{array}$ & $\begin{array}{c}0.063 * \\
{[0.034]}\end{array}$ & $\begin{array}{c}0.088^{* *} \\
{[0.037]}\end{array}$ & $\begin{array}{c}0.131 * * * \\
{[0.032]}\end{array}$ & $\begin{array}{c}0.182^{* * *} \\
{[0.012]}\end{array}$ & $\begin{array}{c}-0.005 \\
{[0.006]}\end{array}$ & $\begin{array}{c}-0.006 \\
{[0.007]}\end{array}$ & $\begin{array}{c}-0.009 \\
{[0.008]}\end{array}$ & $\begin{array}{c}-0.006 \\
{[0.010]}\end{array}$ & $\begin{array}{c}0.009 \\
{[0.018]}\end{array}$ & - \\
\hline Sample size & 369,120 & 240,200 & 174,616 & 110,752 & 51,777 & 13,746 & 355,374 & 226,454 & 160,870 & 97,006 & 38,031 & - \\
\hline R-squared & 0.144 & 0.191 & 0.226 & 0.299 & 0.492 & 0.842 & 0.199 & 0.288 & 0.326 & 0.378 & 0.481 & - \\
\hline
\end{tabular}

Notes: Heteroskedacticity-robust standard errors clustered by day of birth are in parentheses. $* * *, * *$, and $*$ indicate statistical significance at the 1,5 , and 10 percent level respectively. After is an indicator for individuals born after January 1 . Treatment is an indicator that equals 1 for cohorts who experienced an education expansion. The IK bandwidth is the Imbens and Kalyanarman (2012) optimal bandwidth. Coefficients are multuplied by 100 for clarity. The IK bandwidth when excluding 7 days on each side of the cutoff is less than 7 days so these estimates are missing. 
Appendix Table 2: Specification Tests for Covariates (1)

\begin{tabular}{|c|c|c|c|c|c|c|c|c|c|c|c|c|}
\hline \multicolumn{13}{|c|}{ dependent variable: years of schooling } \\
\hline \multirow[b]{2}{*}{ bandwidth (days) } & \multicolumn{6}{|c|}{ Full sample } & \multicolumn{6}{|c|}{ Excluding 7 days on each side of cutoff } \\
\hline & $\begin{array}{l}180 \\
(1)\end{array}$ & $\begin{array}{l}120 \\
(2)\end{array}$ & $\begin{array}{l}90 \\
(3)\end{array}$ & $\begin{array}{l}60 \\
(4)\end{array}$ & $\begin{array}{l}30 \\
(5)\end{array}$ & $\begin{array}{l}\text { IK } \\
(6)\end{array}$ & $\begin{array}{l}180 \\
(1)\end{array}$ & $\begin{array}{l}120 \\
(2)\end{array}$ & $\begin{array}{l}90 \\
(3)\end{array}$ & $\begin{array}{l}60 \\
(4)\end{array}$ & $\begin{array}{l}30 \\
(5)\end{array}$ & $\begin{array}{l}\text { IK } \\
(6)\end{array}$ \\
\hline \multicolumn{13}{|l|}{ Female } \\
\hline After & $\begin{array}{c}-0.025 * * * \\
{[0.009]}\end{array}$ & $\begin{array}{c}-0.038 * * * \\
{[0.012]}\end{array}$ & $\begin{array}{c}-0.050^{* * *} \\
{[0.014]}\end{array}$ & $\begin{array}{c}-0.073 * * * \\
{[0.017]}\end{array}$ & $\begin{array}{c}-0.104 * * * \\
{[0.022]}\end{array}$ & $\begin{array}{c}-0.104 * * * \\
{[0.022]}\end{array}$ & $\begin{array}{c}-0.009 \\
{[0.008]}\end{array}$ & $\begin{array}{c}-0.016 \\
{[0.010]}\end{array}$ & $\begin{array}{l}-0.023 * \\
{[0.012]}\end{array}$ & $\begin{array}{c}-0.047 * * * \\
{[0.016]}\end{array}$ & $\begin{array}{c}-0.101 * * * \\
{[0.025]}\end{array}$ & $\begin{array}{c}-0.036^{* *} \\
{[0.014]}\end{array}$ \\
\hline After*Treatment & $\begin{array}{c}-0.013 \\
{[0.008]}\end{array}$ & $\begin{array}{c}-0.022 * * \\
{[0.010]}\end{array}$ & $\begin{array}{c}-0.028^{* *} \\
{[0.011]}\end{array}$ & $\begin{array}{l}-0.024^{*} \\
{[0.014]}\end{array}$ & $\begin{array}{c}-0.026 \\
{[0.020]}\end{array}$ & $\begin{array}{c}-0.026 \\
{[0.020]}\end{array}$ & $\begin{array}{c}-0.006 \\
{[0.009]}\end{array}$ & $\begin{array}{c}-0.012 \\
{[0.012]}\end{array}$ & $\begin{array}{c}-0.016 \\
{[0.014]}\end{array}$ & $\begin{array}{c}-0.002 \\
{[0.019]}\end{array}$ & $\begin{array}{c}0.050 \\
{[0.031]}\end{array}$ & $\begin{array}{c}-0.012 \\
{[0.017]}\end{array}$ \\
\hline Sample size & 368,798 & 239,939 & 174,350 & 110,734 & 51,777 & 51,777 & 355,052 & 226,193 & 160,604 & 96,988 & 38,031 & 115,133 \\
\hline R-squared & 0.001 & 0.001 & 0.002 & 0.003 & 0.006 & 0.006 & 0.000 & 0.001 & 0.001 & 0.001 & 0.002 & 0.001 \\
\hline \multicolumn{13}{|l|}{ Ethnic Romanian } \\
\hline After & $\begin{array}{c}0.015 * * * \\
{[0.005]}\end{array}$ & $\begin{array}{c}0.024 * * * \\
{[0.006]}\end{array}$ & $\begin{array}{c}0.029 * * * \\
{[0.006]}\end{array}$ & $\begin{array}{c}0.032 * * * \\
{[0.007]}\end{array}$ & $\begin{array}{c}0.033 * * * \\
{[0.011]}\end{array}$ & $\begin{array}{c}0.032 * * * \\
{[0.008]}\end{array}$ & $\begin{array}{l}0.013 * * \\
{[0.005]}\end{array}$ & $\begin{array}{c}0.023 * * * \\
{[0.007]}\end{array}$ & $\begin{array}{c}0.029^{* * *} \\
{[0.008]}\end{array}$ & $\begin{array}{c}0.031 * * * \\
{[0.011]}\end{array}$ & $\begin{array}{c}0.022 \\
{[0.022]}\end{array}$ & $\begin{array}{c}0.032 * * * \\
{[0.010]}\end{array}$ \\
\hline After*Treatment & $\begin{array}{c}-0.008 \\
{[0.005]}\end{array}$ & $\begin{array}{c}-0.011 \\
{[0.007]}\end{array}$ & $\begin{array}{c}-0.012 \\
{[0.008]}\end{array}$ & $\begin{array}{c}-0.012 \\
{[0.010]}\end{array}$ & $\begin{array}{c}-0.007 \\
{[0.014]}\end{array}$ & $\begin{array}{c}-0.010 \\
{[0.011]}\end{array}$ & $\begin{array}{c}-0.009 \\
{[0.005]}\end{array}$ & $\begin{array}{l}-0.014^{*} \\
{[0.007]}\end{array}$ & $\begin{array}{c}-0.017^{* *} \\
{[0.008]}\end{array}$ & $\begin{array}{c}-0.019 * \\
{[0.011]}\end{array}$ & $\begin{array}{c}-0.007 \\
{[0.021]}\end{array}$ & $\begin{array}{l}-0.019^{*} \\
{[0.010]}\end{array}$ \\
\hline Sample size & 368,798 & 239,939 & 174,350 & 110,734 & 51,777 & 90,026 & 355,052 & 226,193 & 160,604 & 96,988 & 38,031 & 109,578 \\
\hline R-squared & 0.001 & 0.001 & 0.001 & 0.001 & 0.002 & 0.001 & 0.001 & 0.001 & 0.001 & 0.001 & 0.001 & 0.001 \\
\hline \multicolumn{13}{|l|}{ Ethnic Hungarian } \\
\hline After & $\begin{array}{c}-0.013 * * * \\
{[0.003]}\end{array}$ & $\begin{array}{c}-0.019 * * * \\
{[0.004]}\end{array}$ & $\begin{array}{c}-0.021 * * * \\
{[0.005]}\end{array}$ & $\begin{array}{c}-0.023 * * * \\
{[0.005]}\end{array}$ & $\begin{array}{c}-0.022 * * * \\
{[0.007]}\end{array}$ & $\begin{array}{c}-0.023 * * * \\
{[0.006]}\end{array}$ & $\begin{array}{c}-0.013 * * * \\
{[0.004]}\end{array}$ & $\begin{array}{c}-0.020 * * * \\
{[0.005]}\end{array}$ & $\begin{array}{c}-0.024 * * * \\
{[0.006]}\end{array}$ & $\begin{array}{c}-0.027 * * * \\
{[0.008]}\end{array}$ & $\begin{array}{c}-0.020 \\
{[0.015]}\end{array}$ & $\begin{array}{c}-0.026^{* * *} \\
{[0.007]}\end{array}$ \\
\hline After*Treatment & $\begin{array}{c}0.006 \\
{[0.004]}\end{array}$ & $\begin{array}{c}0.009 \\
{[0.006]}\end{array}$ & $\begin{array}{c}0.010 \\
{[0.007]}\end{array}$ & $\begin{array}{c}0.012 \\
{[0.008]}\end{array}$ & $\begin{array}{c}0.011 \\
{[0.012]}\end{array}$ & $\begin{array}{c}0.012 \\
{[0.008]}\end{array}$ & $\begin{array}{c}0.005 \\
{[0.005]}\end{array}$ & $\begin{array}{c}0.010 \\
{[0.006]}\end{array}$ & $\begin{array}{c}0.013 \\
{[0.008]}\end{array}$ & $\begin{array}{l}0.018^{*} \\
{[0.011]}\end{array}$ & $\begin{array}{c}0.006 \\
{[0.019]}\end{array}$ & $\begin{array}{l}0.015^{*} \\
{[0.009]}\end{array}$ \\
\hline Sample size & 368,798 & 239,939 & 174,350 & 110,734 & 51,777 & 104,061 & 355,052 & 226,193 & 160,604 & 96,988 & 38,031 & 128,744 \\
\hline R-squared & 0.001 & 0.001 & 0.001 & 0.001 & 0.001 & 0.001 & 0.001 & 0.001 & 0.001 & 0.002 & 0.001 & 0.001 \\
\hline
\end{tabular}

Notes: Heteroskedacticity-robust standard errors clustered by day of birth are in parentheses. $* * *, * *$, and * indicate statistical significance at the 1,5 , and 10 percent level respectively. After is an indicator for individuals born after January 1 . Treatment is an indicator that equals 1 for cohorts who experienced an education expansion. The IK bandwidth is the Imbens and Kalyanarman (2012) optimal bandwidth. 
Appendix Table 3: Specification Tests for Covariates (2)

\begin{tabular}{|c|c|c|c|c|c|c|c|c|c|c|c|c|}
\hline \multicolumn{13}{|c|}{ dependent variable: years of schooling } \\
\hline \multirow{3}{*}{ bandwidth (days) } & \multicolumn{6}{|c|}{ Full sample } & \multicolumn{6}{|c|}{ Excluding 7 days on each side of cutoff } \\
\hline & 180 & 120 & 90 & 60 & 30 & $\mathrm{IK}$ & 180 & 120 & 90 & 60 & 30 & $\mathrm{IK}$ \\
\hline & $(1)$ & $(2)$ & (3) & $(4)$ & $(5)$ & $(6)$ & $(1)$ & $(2)$ & $(3)$ & $(4)$ & $(5)$ & (6) \\
\hline \multicolumn{13}{|l|}{ Ethnic Roma } \\
\hline After & $\begin{array}{l}-0.000 \\
{[0.002]}\end{array}$ & $\begin{array}{c}-0.002 \\
{[0.002]}\end{array}$ & $\begin{array}{c}-0.004 \\
{[0.003]}\end{array}$ & $\begin{array}{c}-0.004 \\
{[0.003]}\end{array}$ & $\begin{array}{l}-0.005 \\
{[0.005]}\end{array}$ & $\begin{array}{c}-0.004 \\
{[0.003]}\end{array}$ & $\begin{array}{c}0.001 \\
{[0.002]}\end{array}$ & $\begin{array}{c}-0.001 \\
{[0.003]}\end{array}$ & $\begin{array}{l}-0.003 \\
{[0.003]}\end{array}$ & $\begin{array}{c}-0.002 \\
{[0.004]}\end{array}$ & $\begin{array}{c}0.006 \\
{[0.008]}\end{array}$ & $\begin{array}{c}-0.002 \\
{[0.004]}\end{array}$ \\
\hline After*Treatment & $\begin{array}{c}0.001 \\
{[0.002]}\end{array}$ & $\begin{array}{c}0.000 \\
{[0.003]}\end{array}$ & $\begin{array}{c}0.000 \\
{[0.003]}\end{array}$ & $\begin{array}{l}-0.001 \\
{[0.005]}\end{array}$ & $\begin{array}{l}-0.005 \\
{[0.008]}\end{array}$ & $\begin{array}{l}-0.002 \\
{[0.005]}\end{array}$ & $\begin{array}{c}0.002 \\
{[0.002]}\end{array}$ & $\begin{array}{c}0.001 \\
{[0.003]}\end{array}$ & $\begin{array}{c}0.001 \\
{[0.003]}\end{array}$ & $\begin{array}{c}-0.002 \\
{[0.004]}\end{array}$ & $\begin{array}{c}-0.012 * \\
{[0.006]}\end{array}$ & $\begin{array}{c}-0.002 \\
{[0.004]}\end{array}$ \\
\hline Sample size & 368,798 & 239,939 & 174,350 & 110,734 & 51,777 & 105,028 & 355,052 & 226,193 & 160,604 & 96,988 & 38,031 & 105,506 \\
\hline R-squared & 0.000 & 0.001 & 0.001 & 0.001 & 0.001 & 0.001 & 0.000 & 0.000 & 0.000 & 0.000 & 0.001 & 0.000 \\
\hline \multicolumn{13}{|l|}{ Ethnic Other } \\
\hline After & $\begin{array}{l}-0.002 \\
{[0.002]}\end{array}$ & $\begin{array}{l}-0.004 * \\
{[0.002]}\end{array}$ & $\begin{array}{l}-0.004 * \\
{[0.003]}\end{array}$ & $\begin{array}{l}-0.004 \\
{[0.003]}\end{array}$ & $\begin{array}{c}-0.006 \\
{[0.004]}\end{array}$ & $\begin{array}{l}-0.004^{*} \\
{[0.002]}\end{array}$ & $\begin{array}{l}-0.001 \\
{[0.002]}\end{array}$ & $\begin{array}{l}-0.002 \\
{[0.003]}\end{array}$ & $\begin{array}{l}-0.003 \\
{[0.003]}\end{array}$ & $\begin{array}{c}-0.002 \\
{[0.005]}\end{array}$ & $\begin{array}{c}-0.008 \\
{[0.011]}\end{array}$ & $\begin{array}{l}-0.001 \\
{[0.002]}\end{array}$ \\
\hline After*Treatment & $\begin{array}{c}0.001 \\
{[0.002]}\end{array}$ & $\begin{array}{c}0.002 \\
{[0.003]}\end{array}$ & $\begin{array}{c}0.002 \\
{[0.003]}\end{array}$ & $\begin{array}{c}0.001 \\
{[0.004]}\end{array}$ & $\begin{array}{c}0.001 \\
{[0.006]}\end{array}$ & $\begin{array}{c}0.002 \\
{[0.003]}\end{array}$ & $\begin{array}{c}0.002 \\
{[0.002]}\end{array}$ & $\begin{array}{c}0.003 \\
{[0.003]}\end{array}$ & $\begin{array}{c}0.003 \\
{[0.004]}\end{array}$ & $\begin{array}{c}0.003 \\
{[0.005]}\end{array}$ & $\begin{array}{c}0.013 \\
{[0.010]}\end{array}$ & $\begin{array}{c}0.001 \\
{[0.002]}\end{array}$ \\
\hline Sample size & 368,798 & 239,939 & 174,350 & 110,734 & 51,777 & 238,075 & 355,052 & 226,193 & 160,604 & 96,988 & 38,031 & 360,792 \\
\hline R-squared & 0.000 & 0.000 & 0.000 & 0.000 & 0.000 & 0.000 & 0.000 & 0.000 & 0.000 & 0.000 & 0.000 & 0.000 \\
\hline \multicolumn{13}{|l|}{ Born in Bucharest } \\
\hline After & $\begin{array}{c}-0.009 * * * \\
{[0.003]}\end{array}$ & $\begin{array}{c}-0.011 * * * \\
{[0.003]}\end{array}$ & $\begin{array}{c}-0.012 * * * \\
{[0.004]}\end{array}$ & $\begin{array}{c}-0.011 * * \\
{[0.005]}\end{array}$ & $\begin{array}{c}-0.014 * * \\
{[0.007]}\end{array}$ & $\begin{array}{c}-0.012 * * \\
{[0.005]}\end{array}$ & $\begin{array}{c}-0.008 * * * \\
{[0.003]}\end{array}$ & $\begin{array}{c}-0.010^{* * *} \\
{[0.004]}\end{array}$ & $\begin{array}{c}-0.010^{* *} \\
{[0.004]}\end{array}$ & $\begin{array}{l}-0.006 \\
{[0.006]}\end{array}$ & $\begin{array}{c}-0.006 \\
{[0.012]}\end{array}$ & $\begin{array}{c}-0.009 * * * \\
{[0.003]}\end{array}$ \\
\hline After*Treatment & $\begin{array}{c}0.002 \\
{[0.003]}\end{array}$ & $\begin{array}{c}0.003 \\
{[0.004]}\end{array}$ & $\begin{array}{c}0.003 \\
{[0.005]}\end{array}$ & $\begin{array}{c}0.001 \\
{[0.006]}\end{array}$ & $\begin{array}{c}0.003 \\
{[0.009]}\end{array}$ & $\begin{array}{c}0.001 \\
{[0.006]}\end{array}$ & $\begin{array}{c}0.004 \\
{[0.003]}\end{array}$ & $\begin{array}{c}0.005 \\
{[0.004]}\end{array}$ & $\begin{array}{c}0.005 \\
{[0.005]}\end{array}$ & $\begin{array}{c}0.002 \\
{[0.008]}\end{array}$ & $\begin{array}{c}0.009 \\
{[0.016]}\end{array}$ & $\begin{array}{c}0.004 \\
{[0.004]}\end{array}$ \\
\hline Sample size & 368,798 & 239,939 & 174,350 & 110,734 & 51,777 & 115,361 & 355,052 & 226,193 & 160,604 & 96,988 & 38,031 & 279,260 \\
\hline R-squared & 0 & 0 & 0.001 & 0.001 & 0.001 & 0.001 & 0 & 0 & 0 & 0.001 & 0.001 & 0 \\
\hline
\end{tabular}

Notes: Heteroskedacticity-robust standard errors clustered by day of birth are in parentheses. ***, **, and * indicate statistical significance at the 1,5 , and 10 percent level respectively. After is an indicator for individuals born after January 1 . Treatment is an indicator that equals 1 for cohorts who experienced an education expansion. The IK bandwidth is the Imbens and Kalyanarman (2012) optimal bandwidth. 
Appendix Table 4: Effects of Educational Expansion on Actual Years of Schooling

\begin{tabular}{|c|c|c|c|c|c|c|c|c|c|c|}
\hline \multirow{3}{*}{$\begin{array}{l}\text { Bandwidth } \\
\text { (months) }\end{array}$} & \multicolumn{5}{|c|}{1994 LSMS } & \multicolumn{5}{|c|}{ 1995-96 LSMS } \\
\hline & 6 & 5 & 4 & 3 & 2 & 6 & 5 & 4 & 3 & 2 \\
\hline & $(1)$ & $(2)$ & (3) & (4) & $(5)$ & $(7)$ & $(8)$ & $(9)$ & $(10)$ & $(11)$ \\
\hline \multicolumn{11}{|c|}{ Panel A: Treated years } \\
\hline After & $\begin{array}{c}0.291 \\
{[0.275]}\end{array}$ & $\begin{array}{c}0.550 * * \\
{[0.212]}\end{array}$ & $\begin{array}{c}0.641 * * \\
{[0.197]}\end{array}$ & $\begin{array}{c}0.981 * * * \\
{[0.149]}\end{array}$ & $\begin{array}{c}1.183 * * * \\
{[0.020]}\end{array}$ & $\begin{array}{c}0.175 \\
{[0.225]}\end{array}$ & $\begin{array}{l}0.356^{*} \\
{[0.189]}\end{array}$ & $\begin{array}{c}0.495 * * * \\
{[0.126]}\end{array}$ & $\begin{array}{c}0.601 * * * \\
{[0.098]}\end{array}$ & $\begin{array}{c}0.837 * * * \\
{[0.014]}\end{array}$ \\
\hline Sample size & 5,294 & 4,376 & 3,439 & 2,526 & 1,596 & 8,383 & 6,909 & 5,416 & 3,909 & 2,421 \\
\hline R-squared & 0.017 & 0.018 & 0.017 & 0.017 & 0.019 & 0.027 & 0.029 & 0.032 & 0.032 & 0.029 \\
\hline \multicolumn{11}{|c|}{ Panel B: Control years } \\
\hline After & $\begin{array}{c}0.107 \\
{[0.321]}\end{array}$ & $\begin{array}{c}0.455 \\
{[0.268]}\end{array}$ & $\begin{array}{c}0.471 * * \\
{[0.172]}\end{array}$ & $\begin{array}{c}0.565^{* * *} \\
{[0.111]}\end{array}$ & $\begin{array}{c}0.724 * * * \\
{[0.025]}\end{array}$ & $\begin{array}{c}-0.029 \\
{[0.194]}\end{array}$ & $\begin{array}{c}-0.110 \\
{[0.151]}\end{array}$ & $\begin{array}{c}-0.156 \\
{[0.250]}\end{array}$ & $\begin{array}{c}0.155 * * \\
{[0.044]}\end{array}$ & $\begin{array}{c}0.129 * * * \\
{[0.004]}\end{array}$ \\
\hline Sample size & 2,356 & 1,968 & 1,550 & 1,143 & 690 & 4,887 & 4,068 & 3,209 & 2,377 & 1,498 \\
\hline R-squared & 0.001 & 0.001 & 0.004 & 0.007 & 0.006 & 0.004 & 0.006 & 0.003 & 0.006 & 0.003 \\
\hline \multicolumn{11}{|c|}{ Panel C: All years } \\
\hline After & $\begin{array}{c}0.107 \\
{[0.321]}\end{array}$ & $\begin{array}{c}0.455 \\
{[0.268]}\end{array}$ & $\begin{array}{c}0.471 * * \\
{[0.172]}\end{array}$ & $\begin{array}{c}0.565 * * * \\
{[0.111]}\end{array}$ & $\begin{array}{c}0.724 * * * \\
{[0.025]}\end{array}$ & $\begin{array}{l}-0.029 \\
{[0.194]}\end{array}$ & $\begin{array}{c}-0.110 \\
{[0.151]}\end{array}$ & $\begin{array}{l}-0.156 \\
{[0.250]}\end{array}$ & $\begin{array}{c}0.155 * * \\
{[0.044]}\end{array}$ & $\begin{array}{c}0.129 * * * \\
{[0.004]}\end{array}$ \\
\hline After*Treatment & $\begin{array}{c}0.184 \\
{[0.267]}\end{array}$ & $\begin{array}{c}0.095 \\
{[0.270]}\end{array}$ & $\begin{array}{c}0.169 \\
{[0.197]}\end{array}$ & $\begin{array}{c}0.416 \\
{[0.210]}\end{array}$ & $\begin{array}{c}0.458 * * * \\
{[0.033]}\end{array}$ & $\begin{array}{c}0.204 \\
{[0.184]}\end{array}$ & $\begin{array}{l}0.466 * * \\
{[0.167]}\end{array}$ & $\begin{array}{l}0.651 * * \\
{[0.220]}\end{array}$ & $\begin{array}{c}0.446 * * * \\
{[0.102]}\end{array}$ & $\begin{array}{c}0.708 * * * \\
{[0.013]}\end{array}$ \\
\hline Sample size & 7,650 & 6,344 & 4,989 & 3,669 & 2,286 & 13,270 & 10,977 & 8,625 & 6,286 & 3,919 \\
\hline R-squared & 0.040 & 0.042 & 0.046 & 0.050 & 0.044 & 0.041 & 0.043 & 0.046 & 0.043 & 0.042 \\
\hline
\end{tabular}

Notes: Heteroskedacticity-robust standard errors clustered by day of birth are in parentheses. $* * *, * *$, and * indicate statistical significance at the 1 , 5, and 10 percent level respectively. After is an indicator for individuals born after January 1. Treatment is an indicator that equals 1 for cohorts who experienced an education expansion. The IK bandwidth is the Imbens and Kalyanarman (2012) optimal bandwidth. 


\begin{tabular}{|c|c|c|c|c|c|c|c|c|c|c|c|c|}
\hline \multirow{3}{*}{$\begin{array}{l}\text { Bandwidth } \\
\text { (days) }\end{array}$} & \multicolumn{6}{|c|}{ Full sample } & \multicolumn{6}{|c|}{ Excluding 7 days on each side of cutoff } \\
\hline & 180 & 120 & 90 & 60 & 30 & IK & 180 & 120 & 90 & 60 & 30 & IK \\
\hline & $(1)$ & $(2)$ & (3) & (4) & $(5)$ & $(6)$ & (7) & $(8)$ & $(9)$ & $(10)$ & $(11)$ & $(12)$ \\
\hline \multicolumn{13}{|c|}{ Panel A: Treated years } \\
\hline After & $\begin{array}{c}0.000 \\
{[0.002]}\end{array}$ & $\begin{array}{c}-0.000 \\
{[0.003]}\end{array}$ & $\begin{array}{c}-0.001 \\
{[0.003]}\end{array}$ & $\begin{array}{c}-0.001 \\
{[0.003]}\end{array}$ & $\begin{array}{c}-0.003 \\
{[0.004]}\end{array}$ & $\begin{array}{c}-0.001 \\
{[0.003]}\end{array}$ & $\begin{array}{c}0.001 \\
{[0.002]}\end{array}$ & $\begin{array}{c}0.000 \\
{[0.003]}\end{array}$ & $\begin{array}{c}-0.000 \\
{[0.004]}\end{array}$ & $\begin{array}{c}0.000 \\
{[0.006]}\end{array}$ & $\begin{array}{c}-0.003 \\
{[0.012]}\end{array}$ & $\begin{array}{c}0.000 \\
{[0.002]}\end{array}$ \\
\hline Sample size & 2,154 & 1,434 & 1,074 & 714 & 354 & 1,236 & 2,070 & 1,350 & 990 & 630 & 270 & 2,105 \\
\hline R-squared & 0.023 & 0.022 & 0.020 & 0.024 & 0.047 & 0.021 & 0.025 & 0.026 & 0.025 & 0.031 & 0.056 & 0.025 \\
\hline \multicolumn{13}{|c|}{ Panel B: Control years } \\
\hline After & $\begin{array}{c}-0.002 \\
{[0.002]}\end{array}$ & $\begin{array}{c}-0.002 \\
{[0.003]}\end{array}$ & $\begin{array}{c}-0.002 \\
{[0.003]}\end{array}$ & $\begin{array}{c}-0.003 \\
{[0.004]}\end{array}$ & $\begin{array}{c}-0.010^{*} \\
{[0.006]}\end{array}$ & $\begin{array}{c}-0.002 \\
{[0.003]}\end{array}$ & $\begin{array}{c}-0.000 \\
{[0.002]}\end{array}$ & $\begin{array}{c}0.002 \\
{[0.003]}\end{array}$ & $\begin{array}{c}0.003 \\
{[0.003]}\end{array}$ & $\begin{array}{c}0.005 \\
{[0.003]}\end{array}$ & $\begin{array}{c}0.002 \\
{[0.006]}\end{array}$ & $\begin{array}{c}-0.001 \\
{[0.002]}\end{array}$ \\
\hline Sample size & 1,077 & 717 & 537 & 357 & 177 & 618 & 1,035 & 675 & 495 & 315 & 135 & 1,053 \\
\hline R-squared & 0.025 & 0.025 & 0.026 & 0.027 & 0.067 & 0.026 & 0.019 & 0.021 & 0.021 & 0.017 & 0.016 & 0.021 \\
\hline \multicolumn{13}{|c|}{ Panel C: All years } \\
\hline After & $\begin{array}{c}-0.002 \\
{[0.002]}\end{array}$ & $\begin{array}{c}-0.002 \\
{[0.003]}\end{array}$ & $\begin{array}{c}-0.002 \\
{[0.003]}\end{array}$ & $\begin{array}{c}-0.003 \\
{[0.004]}\end{array}$ & $\begin{array}{c}-0.010^{*} \\
{[0.006]}\end{array}$ & $\begin{array}{c}-0.002 \\
{[0.003]}\end{array}$ & $\begin{array}{l}-0.000 \\
{[0.002]}\end{array}$ & $\begin{array}{c}0.002 \\
{[0.003]}\end{array}$ & $\begin{array}{c}0.003 \\
{[0.003]}\end{array}$ & $\begin{array}{c}0.005 \\
{[0.003]}\end{array}$ & $\begin{array}{c}0.002 \\
{[0.006]}\end{array}$ & $\begin{array}{c}-0.001 \\
{[0.002]}\end{array}$ \\
\hline After*Treatment & $\begin{array}{c}0.002 \\
{[0.003]}\end{array}$ & $\begin{array}{c}0.001 \\
{[0.004]}\end{array}$ & $\begin{array}{c}0.001 \\
{[0.004]}\end{array}$ & $\begin{array}{c}0.002 \\
{[0.005]}\end{array}$ & $\begin{array}{c}0.007 \\
{[0.006]}\end{array}$ & $\begin{array}{c}0.001 \\
{[0.004]}\end{array}$ & $\begin{array}{c}0.001 \\
{[0.003]}\end{array}$ & $\begin{array}{c}-0.002 \\
{[0.005]}\end{array}$ & $\begin{array}{c}-0.004 \\
{[0.006]}\end{array}$ & $\begin{array}{c}-0.005 \\
{[0.008]}\end{array}$ & $\begin{array}{c}-0.005 \\
{[0.014]}\end{array}$ & $\begin{array}{c}0.001 \\
{[0.003]}\end{array}$ \\
\hline Sample size & 3,231 & 2,151 & 1,611 & 1,071 & 531 & 1,854 & 3,105 & 2,025 & 1,485 & 945 & 405 & 3,158 \\
\hline R-squared & 0.057 & 0.056 & 0.051 & 0.049 & 0.070 & 0.053 & 0.061 & 0.061 & 0.058 & 0.055 & 0.070 & 0.059 \\
\hline
\end{tabular}

Notes: Heteroskedacticity-robust standard errors clustered by day of birth are in parentheses. $* * *, * *$, and * indicate statistical significance at the 1,5 , and 10 percent level respectively. After is an indicator for individuals born after January 1 . Treatment is an indicator that equals 1 for cohorts who experienced an education expansion. The IK bandwidth is the Imbens and Kalyanarman (2012) optimal bandwidth. The preventable causes of death include: Lung cancer (C33C34), Cirrhosis of liver (K70, K74.3-K74.6), External causes of death (V, W, X, Y). 
Appendix Table 6: Effects of Educational Expansion on Mortality Rate due to Treatable Diseases

\begin{tabular}{|c|c|c|c|c|c|c|c|c|c|c|c|c|}
\hline \multirow{3}{*}{$\begin{array}{l}\text { Bandwidth } \\
\text { (days) }\end{array}$} & \multicolumn{6}{|c|}{ Full sample } & \multicolumn{6}{|c|}{ Excluding 7 days on each side of cutoff } \\
\hline & 180 & 120 & 90 & 60 & 30 & IK & 180 & 120 & 90 & 60 & 30 & IK \\
\hline & $(1)$ & (2) & (3) & (4) & $(5)$ & $(6)$ & $(7)$ & (8) & $(9)$ & $(10)$ & $(11)$ & $(12)$ \\
\hline \multicolumn{13}{|c|}{ Panel A: Treated years } \\
\hline After & $\begin{array}{c}0.002 \\
{[0.002]}\end{array}$ & $\begin{array}{c}0.001 \\
{[0.002]}\end{array}$ & $\begin{array}{c}-0.000 \\
{[0.002]}\end{array}$ & $\begin{array}{c}-0.001 \\
{[0.002]}\end{array}$ & $\begin{array}{c}-0.003 \\
{[0.003]}\end{array}$ & $\begin{array}{c}0.001 \\
{[0.002]}\end{array}$ & $\begin{array}{c}0.002 \\
{[0.002]}\end{array}$ & $\begin{array}{c}0.002 \\
{[0.002]}\end{array}$ & $\begin{array}{c}0.001 \\
{[0.003]}\end{array}$ & $\begin{array}{c}0.001 \\
{[0.004]}\end{array}$ & $\begin{array}{c}-0.002 \\
{[0.008]}\end{array}$ & $\begin{array}{c}0.002 \\
{[0.002]}\end{array}$ \\
\hline Sample size & 2,154 & 1,434 & 1,074 & 714 & 354 & 1,638 & 2,070 & 1,350 & 990 & 630 & 270 & 1,974 \\
\hline R-squared & 0.106 & 0.102 & 0.095 & 0.096 & 0.101 & 0.103 & 0.111 & 0.108 & 0.103 & 0.109 & 0.133 & 0.110 \\
\hline \multicolumn{13}{|c|}{ Panel B: Control years } \\
\hline After & $\begin{array}{c}-0.002 \\
{[0.001]}\end{array}$ & $\begin{array}{c}-0.002 \\
{[0.001]}\end{array}$ & $\begin{array}{c}-0.003 * * \\
{[0.002]}\end{array}$ & $\begin{array}{c}-0.004 * * \\
{[0.002]}\end{array}$ & $\begin{array}{c}-0.007 * * * \\
{[0.002]}\end{array}$ & $\begin{array}{c}-0.002 \\
{[0.001]}\end{array}$ & $\begin{array}{c}-0.000 \\
{[0.001]}\end{array}$ & $\begin{array}{c}-0.000 \\
{[0.002]}\end{array}$ & $\begin{array}{l}-0.001 \\
{[0.002]}\end{array}$ & $\begin{array}{c}0.001 \\
{[0.002]}\end{array}$ & $\begin{array}{c}0.001 \\
{[0.005]}\end{array}$ & $\begin{array}{c}-0.000 \\
{[0.001]}\end{array}$ \\
\hline Sample size & 1,077 & 717 & 537 & 357 & 177 & 819 & 1,035 & 675 & 495 & 315 & 135 & 987 \\
\hline R-squared & 0.045 & 0.045 & 0.051 & 0.055 & 0.094 & 0.043 & 0.038 & 0.031 & 0.031 & 0.027 & 0.026 & 0.037 \\
\hline \multicolumn{13}{|c|}{ Panel C: All years } \\
\hline After & $\begin{array}{c}-0.002 \\
{[0.001]}\end{array}$ & $\begin{array}{c}-0.002 \\
{[0.001]}\end{array}$ & $\begin{array}{c}-0.003 * * \\
{[0.002]}\end{array}$ & $\begin{array}{c}-0.004 * * \\
{[0.002]}\end{array}$ & $\begin{array}{c}-0.007 * * * \\
{[0.002]}\end{array}$ & $\begin{array}{c}-0.002 \\
{[0.001]}\end{array}$ & $\begin{array}{c}-0.000 \\
{[0.001]}\end{array}$ & $\begin{array}{c}-0.000 \\
{[0.002]}\end{array}$ & $\begin{array}{l}-0.001 \\
{[0.002]}\end{array}$ & $\begin{array}{c}0.001 \\
{[0.002]}\end{array}$ & $\begin{array}{c}0.001 \\
{[0.005]}\end{array}$ & $\begin{array}{c}-0.000 \\
{[0.001]}\end{array}$ \\
\hline After*Treatment & $\begin{array}{c}0.003 \\
{[0.002]}\end{array}$ & $\begin{array}{c}0.003 \\
{[0.002]}\end{array}$ & $\begin{array}{c}0.003 \\
{[0.003]}\end{array}$ & $\begin{array}{c}0.003 \\
{[0.003]}\end{array}$ & $\begin{array}{c}0.004 \\
{[0.004]}\end{array}$ & $\begin{array}{c}0.003 \\
{[0.002]}\end{array}$ & $\begin{array}{c}0.003 \\
{[0.002]}\end{array}$ & $\begin{array}{c}0.002 \\
{[0.003]}\end{array}$ & $\begin{array}{c}0.002 \\
{[0.004]}\end{array}$ & $\begin{array}{c}0.001 \\
{[0.005]}\end{array}$ & $\begin{array}{c}-0.003 \\
{[0.011]}\end{array}$ & $\begin{array}{c}0.002 \\
{[0.003]}\end{array}$ \\
\hline Sample size & 3,231 & 2,151 & 1,611 & 1,071 & 531 & 2,457 & 3,105 & 2,025 & 1,485 & 945 & 405 & 2,961 \\
\hline R-squared & 0.224 & 0.218 & 0.211 & 0.200 & 0.191 & 0.220 & 0.228 & 0.224 & 0.216 & 0.208 & 0.201 & 0.228 \\
\hline
\end{tabular}

Notes: Heteroskedacticity-robust standard errors clustered by day of birth are in parentheses. ***,**, and * indicate statistical significance at the 1,5 , and 10 percent

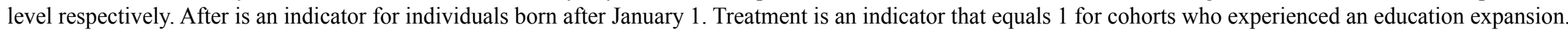

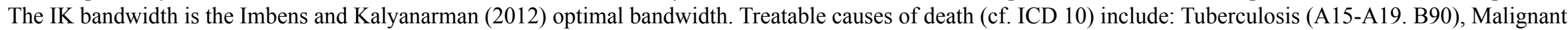

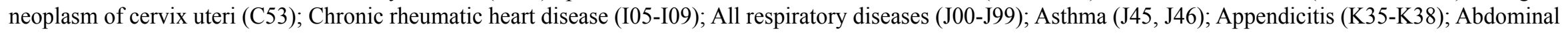
hernia (K40-K46); Hypertensive and cerebrovascular disease (I10-I15, I60-I69); Chollelthiasis and cholecystitis (K80-K81). 
Appendix Table 7: Effect of Educational Expansion on Fertility

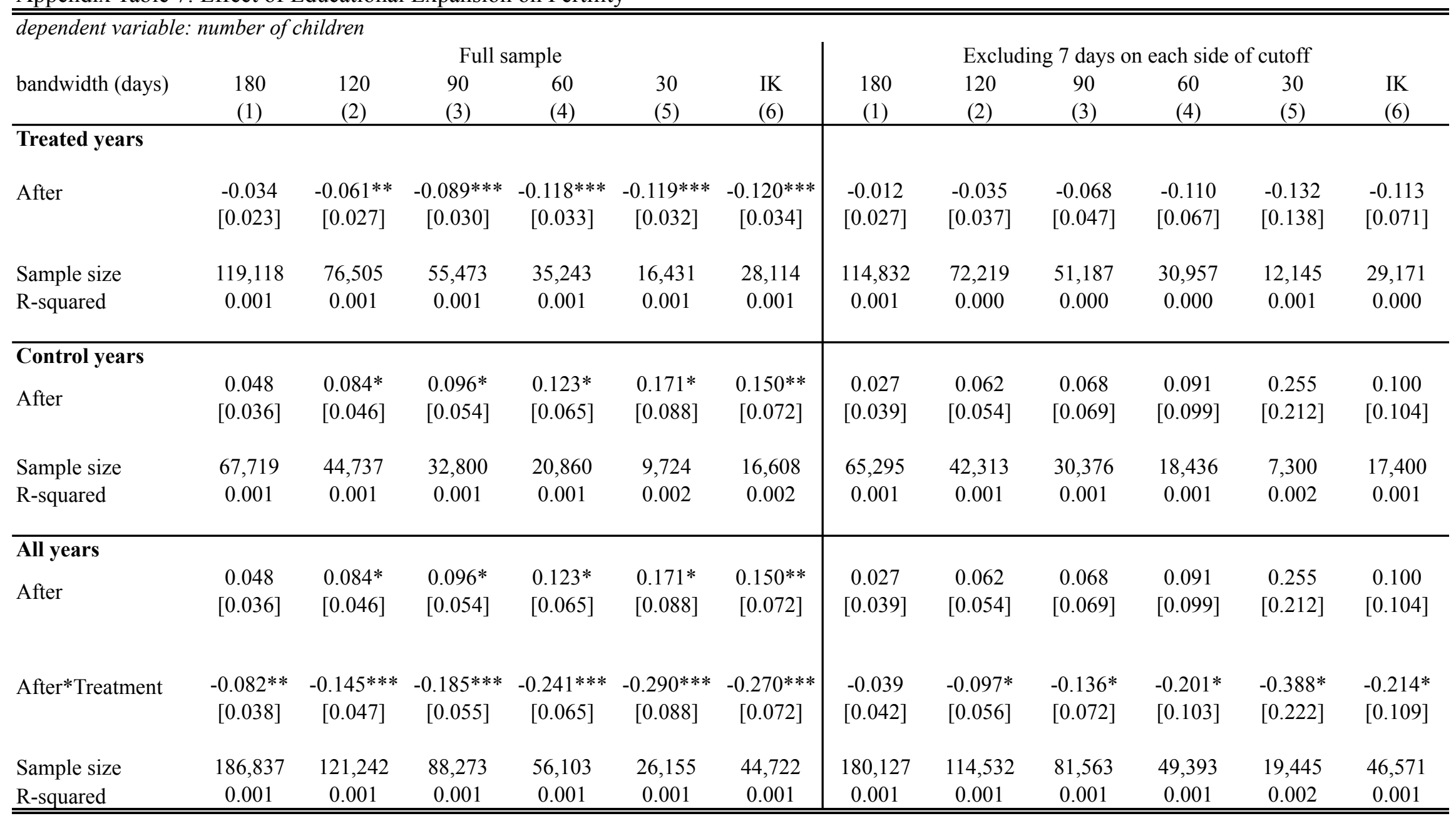

Notes: Heteroskedacticity-robust standard errors clustered by day of birth are in parentheses. $* * *, * *$, and $*$ indicate statistical significance at the 1,5 , and 10 percent level respectively. After is an indicator for individuals born after January 1. Treatment is an indicator that equals 1 for cohorts who experienced an education expansion. The IK bandwidth is the Imbens and Kalyanarman (2012) optimal bandwidth. 
Appendix Table 8: Effect of Educational Expansion on International Migration in the 2011 census

\begin{tabular}{|c|c|c|c|c|c|c|c|c|c|c|c|c|}
\hline \multicolumn{12}{|c|}{ dependent variable: migration rate } & Excluding 7 days on each side of cutoff \\
\hline \multirow[t]{2}{*}{ bandwidth (days) } & 180 & 120 & 90 & 60 & 30 & $\mathrm{IK}$ & 180 & 120 & 90 & 60 & 30 & $\mathrm{IK}$ \\
\hline & $(1)$ & $(2)$ & $(3)$ & $(4)$ & $(5)$ & $(6)$ & $(1)$ & $(2)$ & $(3)$ & $(4)$ & $(5)$ & $(6)$ \\
\hline \multicolumn{13}{|l|}{ Treated years } \\
\hline After & $\begin{array}{c}-0.000 \\
{[0.000]}\end{array}$ & $\begin{array}{c}-0.000 \\
{[0.000]}\end{array}$ & $\begin{array}{c}-0.000 \\
{[0.000]}\end{array}$ & $\begin{array}{c}-0.001 \\
{[0.001]}\end{array}$ & $\begin{array}{c}0.000 \\
{[0.001]}\end{array}$ & $\begin{array}{c}-0.000 \\
{[0.000]}\end{array}$ & $\begin{array}{c}-0.001 * \\
{[0.000]}\end{array}$ & $\begin{array}{c}-0.001 * * \\
{[0.000]}\end{array}$ & $\begin{array}{c}-0.001 * \\
{[0.000]}\end{array}$ & $\begin{array}{c}-0.001 * * \\
{[0.001]}\end{array}$ & $\begin{array}{c}-0.001 \\
{[0.001]}\end{array}$ & $\begin{array}{l}-0.001 * \\
{[0.000]}\end{array}$ \\
\hline Sample size & 2,170 & 1,448 & 1,085 & 718 & 354 & 1,430 & 2,086 & 1,364 & 1,001 & 634 & 270 & 1,672 \\
\hline R-squared & 0.182 & 0.191 & 0.195 & 0.197 & 0.202 & 0.191 & 0.176 & 0.182 & 0.184 & 0.181 & 0.168 & 0.178 \\
\hline \multicolumn{13}{|l|}{ Control years } \\
\hline After & $\begin{array}{c}-0.000 \\
{[0.001]}\end{array}$ & $\begin{array}{c}-0.000 \\
{[0.001]}\end{array}$ & $\begin{array}{c}-0.001 \\
{[0.001]}\end{array}$ & $\begin{array}{c}-0.001 \\
{[0.001]}\end{array}$ & $\begin{array}{c}-0.002 * * \\
{[0.001]}\end{array}$ & $\begin{array}{c}-0.000 \\
{[0.001]}\end{array}$ & $\begin{array}{c}0.000 \\
{[0.001]}\end{array}$ & $\begin{array}{c}0.000 \\
{[0.001]}\end{array}$ & $\begin{array}{c}0.000 \\
{[0.001]}\end{array}$ & $\begin{array}{c}0.001 \\
{[0.001]}\end{array}$ & $\begin{array}{c}-0.001 \\
{[0.001]}\end{array}$ & $\begin{array}{c}0.000 \\
{[0.001]}\end{array}$ \\
\hline Sample size & 1,080 & 719 & 538 & 357 & 177 & 710 & 1,038 & 677 & 496 & 315 & 135 & 831 \\
\hline R-squared & 0.090 & 0.096 & 0.096 & 0.089 & 0.119 & 0.096 & 0.099 & 0.105 & 0.104 & 0.105 & 0.133 & 0.101 \\
\hline \multicolumn{13}{|l|}{ All years } \\
\hline After & $\begin{array}{c}-0.000 \\
{[0.001]}\end{array}$ & $\begin{array}{c}-0.000 \\
{[0.001]}\end{array}$ & $\begin{array}{c}-0.001 \\
{[0.001]}\end{array}$ & $\begin{array}{c}-0.001 \\
{[0.001]}\end{array}$ & $\begin{array}{c}-0.002 * * \\
{[0.001]}\end{array}$ & $\begin{array}{c}-0.000 \\
{[0.001]}\end{array}$ & $\begin{array}{c}0.000 \\
{[0.001]}\end{array}$ & $\begin{array}{c}0.000 \\
{[0.001]}\end{array}$ & $\begin{array}{c}0.000 \\
{[0.001]}\end{array}$ & $\begin{array}{c}0.001 \\
{[0.001]}\end{array}$ & $\begin{array}{c}-0.001 \\
{[0.001]}\end{array}$ & $\begin{array}{c}0.000 \\
{[0.001]}\end{array}$ \\
\hline After*Treatment & $\begin{array}{c}-0.000 \\
{[0.001]}\end{array}$ & $\begin{array}{c}-0.000 \\
{[0.001]}\end{array}$ & $\begin{array}{c}0.000 \\
{[0.001]}\end{array}$ & $\begin{array}{c}0.000 \\
{[0.001]}\end{array}$ & $\begin{array}{c}0.002 * * \\
{[0.001]}\end{array}$ & $\begin{array}{c}-0.000 \\
{[0.001]}\end{array}$ & $\begin{array}{c}-0.001 \\
{[0.001]}\end{array}$ & $\begin{array}{c}-0.001 \\
{[0.001]}\end{array}$ & $\begin{array}{c}-0.001 \\
{[0.001]}\end{array}$ & $\begin{array}{c}-0.002 * \\
{[0.001]}\end{array}$ & $\begin{array}{c}0.000 \\
{[0.002]}\end{array}$ & $\begin{array}{c}-0.001 \\
{[0.001]}\end{array}$ \\
\hline Sample size & 3,250 & 2,167 & 1,623 & 1,075 & 531 & 2,140 & 3,124 & 2,041 & 1,497 & 949 & 405 & 2,503 \\
\hline R-squared & 0.364 & 0.367 & 0.371 & 0.382 & 0.420 & 0.367 & 0.355 & 0.351 & 0.348 & 0.351 & 0.353 & 0.352 \\
\hline
\end{tabular}

Notes: Heteroskedacticity-robust standard errors clustered by day of birth are in parentheses. $* * *, * *$, and * indicate statistical significance at the 1,5 , and 10 percent

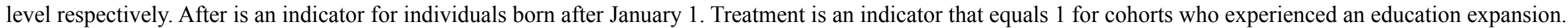
The IK bandwidth is the Imbens and Kalyanarman (2012) optimal bandwidth. 
Appendix Table 9: Effect of Educational Expansion on Attrition between the 1992 and 2011 census

\begin{tabular}{|c|c|c|c|c|c|c|c|c|c|c|c|c|}
\hline \multicolumn{13}{|c|}{ dependent variable: attrition rate } \\
\hline \multirow[t]{2}{*}{ bandwidth (days) } & 180 & 120 & 90 & 60 & 30 & IK & 180 & 120 & 90 & 60 & 30 & IK \\
\hline & $(1)$ & $(2)$ & (3) & (4) & $(5)$ & $(6)$ & $(1)$ & $(2)$ & $(3)$ & $(4)$ & $(5)$ & $(6)$ \\
\hline \multicolumn{13}{|l|}{ Treated years } \\
\hline After & $\begin{array}{c}-0.008 \\
{[0.025]}\end{array}$ & $\begin{array}{c}-0.017 \\
{[0.031]}\end{array}$ & $\begin{array}{c}-0.020 \\
{[0.035]}\end{array}$ & $\begin{array}{c}-0.015 \\
{[0.040]}\end{array}$ & $\begin{array}{c}-0.026 \\
{[0.043]}\end{array}$ & $\begin{array}{c}-0.020 \\
{[0.036]}\end{array}$ & $\begin{array}{c}-0.012 \\
{[0.029]}\end{array}$ & $\begin{array}{c}-0.027 \\
{[0.040]}\end{array}$ & $\begin{array}{c}-0.035 \\
{[0.051]}\end{array}$ & $\begin{array}{c}-0.033 \\
{[0.073]}\end{array}$ & $\begin{array}{c}-0.102 \\
{[0.151]}\end{array}$ & $\begin{array}{c}-0.018 \\
{[0.034]}\end{array}$ \\
\hline Sample size & 2,155 & 1,435 & 1,075 & 714 & 354 & 1,045 & 2,071 & 1,351 & 991 & 630 & 270 & 1,645 \\
\hline R-squared & 0.017 & 0.023 & 0.030 & 0.038 & 0.075 & 0.031 & 0.014 & 0.015 & 0.017 & 0.019 & 0.049 & 0.014 \\
\hline \multicolumn{13}{|l|}{ Control years } \\
\hline After & $\begin{array}{c}-0.058 * * \\
{[0.026]}\end{array}$ & $\begin{array}{c}-0.060 * \\
{[0.031]}\end{array}$ & $\begin{array}{c}-0.064 * \\
{[0.035]}\end{array}$ & $\begin{array}{c}-0.071 * \\
{[0.039]}\end{array}$ & $\begin{array}{c}-0.156^{* * *} \\
{[0.054]}\end{array}$ & $\begin{array}{c}-0.065^{*} \\
{[0.035]}\end{array}$ & $\begin{array}{c}-0.031 \\
{[0.029]}\end{array}$ & $\begin{array}{c}-0.016 \\
{[0.036]}\end{array}$ & $\begin{array}{c}-0.003 \\
{[0.041]}\end{array}$ & $\begin{array}{c}0.034 \\
{[0.045]}\end{array}$ & $\begin{array}{c}-0.037 \\
{[0.084]}\end{array}$ & $\begin{array}{c}-0.023 \\
{[0.033]}\end{array}$ \\
\hline Sample size & 1,078 & 718 & 538 & 357 & 177 & 523 & 1,036 & 676 & 496 & 315 & 135 & 823 \\
\hline R-squared & 0.015 & 0.023 & 0.027 & 0.023 & 0.061 & 0.027 & 0.010 & 0.017 & 0.021 & 0.015 & 0.010 & 0.014 \\
\hline \multicolumn{13}{|l|}{ All years } \\
\hline After & $\begin{array}{c}-0.058 * * \\
{[0.026]}\end{array}$ & $\begin{array}{c}-0.060 * \\
{[0.031]}\end{array}$ & $\begin{array}{c}-0.064 * \\
{[0.035]}\end{array}$ & $\begin{array}{c}-0.071^{*} \\
{[0.039]}\end{array}$ & $\begin{array}{c}-0.156 * * * \\
{[0.054]}\end{array}$ & $\begin{array}{c}-0.065^{*} \\
{[0.035]}\end{array}$ & $\begin{array}{c}-0.031 \\
{[0.029]}\end{array}$ & $\begin{array}{c}-0.016 \\
{[0.036]}\end{array}$ & $\begin{array}{c}-0.003 \\
{[0.041]}\end{array}$ & $\begin{array}{c}0.034 \\
{[0.045]}\end{array}$ & $\begin{array}{c}-0.037 \\
{[0.084]}\end{array}$ & $\begin{array}{c}-0.023 \\
{[0.033]}\end{array}$ \\
\hline After*Treatment & $\begin{array}{c}0.050 \\
{[0.039]}\end{array}$ & $\begin{array}{c}0.043 \\
{[0.047]}\end{array}$ & $\begin{array}{c}0.044 \\
{[0.053]}\end{array}$ & $\begin{array}{c}0.057 \\
{[0.059]}\end{array}$ & $\begin{array}{l}0.130 * * \\
{[0.060]}\end{array}$ & $\begin{array}{c}0.045 \\
{[0.053]}\end{array}$ & $\begin{array}{c}0.019 \\
{[0.045]}\end{array}$ & $\begin{array}{c}-0.011 \\
{[0.060]}\end{array}$ & $\begin{array}{c}-0.032 \\
{[0.074]}\end{array}$ & $\begin{array}{c}-0.067 \\
{[0.100]}\end{array}$ & $\begin{array}{c}-0.065 \\
{[0.198]}\end{array}$ & $\begin{array}{c}0.005 \\
{[0.052]}\end{array}$ \\
\hline Sample size & 3,233 & 2,153 & 1,613 & 1,071 & 531 & 1,568 & 3,107 & 2,027 & 1,487 & 945 & 405 & 2,468 \\
\hline R-squared & 0.022 & 0.028 & 0.036 & 0.045 & 0.088 & 0.037 & 0.016 & 0.018 & 0.022 & 0.023 & 0.043 & 0.017 \\
\hline
\end{tabular}

Notes: Heteroskedacticity-robust standard errors clustered by day of birth are in parentheses. $* * *, * *$, and $*$ indicate statistical significance at the 1,5 , and 10 percent level respectively. After is an indicator for individuals born after January 1. Treatment is an indicator that equals 1 for cohorts who experienced an education expansion. The IK bandwidth is the Imbens and Kalyanarman (2012) optimal bandwidth. 
Appendix Table 10: Effects of Educational Expansion on Employment and Income in the 1995-2000 LSMS data

\begin{tabular}{|c|c|c|c|c|c|c|c|c|c|c|}
\hline \multirow{3}{*}{$\begin{array}{l}\text { Bandwidth } \\
\text { (months) }\end{array}$} & \multicolumn{5}{|c|}{ Employment } & \multicolumn{5}{|c|}{ Log Income } \\
\hline & 6 & 5 & 4 & 3 & 2 & 6 & 5 & 4 & 3 & 2 \\
\hline & $(1)$ & $(2)$ & $(3)$ & $(4)$ & $(5)$ & (7) & $(8)$ & (9) & $(10)$ & $(11)$ \\
\hline \multicolumn{11}{|c|}{ Panel A: Treated years } \\
\hline After & $\begin{array}{c}-0.0006 \\
{[0.0120]}\end{array}$ & $\begin{array}{c}0.0127 \\
{[0.0096]}\end{array}$ & $\begin{array}{l}0.0188 * \\
{[0.0094]}\end{array}$ & $\begin{array}{l}0.0227^{*} \\
{[0.0096]}\end{array}$ & $\begin{array}{c}0.0341 * * * \\
{[0.0011]}\end{array}$ & $\begin{array}{c}-0.0130 \\
{[0.0260]}\end{array}$ & $\begin{array}{c}0.0079 \\
{[0.0232]}\end{array}$ & $\begin{array}{c}0.0122 \\
{[0.0266]}\end{array}$ & $\begin{array}{c}0.0299 \\
{[0.0209]}\end{array}$ & $\begin{array}{c}0.0675^{* * *} * \\
{[0.0009]}\end{array}$ \\
\hline Sample size & 40,558 & 33,512 & 26,211 & 19,089 & 12,005 & 40,234 & 33,245 & 26,012 & 18,955 & 11,920 \\
\hline R-squared & 0.016 & 0.016 & 0.015 & 0.014 & 0.013 & 0.010 & 0.010 & 0.010 & 0.009 & 0.010 \\
\hline \multicolumn{11}{|c|}{ Panel B: Control years } \\
\hline After & $\begin{array}{c}-0.0239 * \\
{[0.0111]}\end{array}$ & $\begin{array}{c}-0.0132 \\
{[0.0112]}\end{array}$ & $\begin{array}{c}-0.0224 \\
{[0.0143]}\end{array}$ & $\begin{array}{l}-0.0188 \\
{[0.0130]}\end{array}$ & $\begin{array}{c}-0.0131 * * * \\
{[0.0015]}\end{array}$ & $\begin{array}{c}-0.0337 \\
{[0.0412]}\end{array}$ & $\begin{array}{c}-0.0275 \\
{[0.0426]}\end{array}$ & $\begin{array}{c}-0.0286 \\
{[0.0506]}\end{array}$ & $\begin{array}{c}0.0105 \\
{[0.0438]}\end{array}$ & $\begin{array}{c}0.0905 * * * \\
{[0.0021]}\end{array}$ \\
\hline Sample size & 23,158 & 19,268 & 15,220 & 11,251 & 7,129 & 22,999 & 19,140 & 15,119 & 11,178 & 7,092 \\
\hline R-squared & 0.001 & 0.001 & 0.001 & 0.001 & 0.001 & 0.001 & 0.002 & 0.001 & 0.002 & 0.004 \\
\hline \multicolumn{11}{|c|}{ Panel C: All years } \\
\hline After & $\begin{array}{c}-0.0239 * \\
{[0.0111]}\end{array}$ & $\begin{array}{c}-0.0132 \\
{[0.0112]}\end{array}$ & $\begin{array}{c}-0.0224 \\
{[0.0143]}\end{array}$ & $\begin{array}{l}-0.0188 \\
{[0.0130]}\end{array}$ & $\begin{array}{c}-0.0131 * * * \\
{[0.0015]}\end{array}$ & $\begin{array}{c}-0.0337 \\
{[0.0412]}\end{array}$ & $\begin{array}{c}-0.0275 \\
{[0.0426]}\end{array}$ & $\begin{array}{c}-0.0286 \\
{[0.0506]}\end{array}$ & $\begin{array}{c}0.0105 \\
{[0.0438]}\end{array}$ & $\begin{array}{c}0.0905 * * * \\
{[0.0021]}\end{array}$ \\
\hline After*Treatment & $\begin{array}{c}0.0234 * * * \\
{[0.0070]}\end{array}$ & $\begin{array}{c}0.0259 * * \\
{[0.0082]}\end{array}$ & $\begin{array}{c}0.0412 * * * \\
{[0.0064]}\end{array}$ & $\begin{array}{c}0.0415 * * * \\
{[0.0044]}\end{array}$ & $\begin{array}{c}0.0473 * * * \\
{[0.0018]}\end{array}$ & $\begin{array}{c}0.0207 \\
{[0.0202]}\end{array}$ & $\begin{array}{c}0.0355 \\
{[0.0217]}\end{array}$ & $\begin{array}{c}0.0408 \\
{[0.0282]}\end{array}$ & $\begin{array}{c}0.0195 \\
{[0.0229]}\end{array}$ & $\begin{array}{c}-0.0230 * * * \\
{[0.0013]}\end{array}$ \\
\hline Sample size & 63,716 & 52,780 & 41,431 & 30,340 & 19,134 & 63,233 & 52,385 & 41,131 & 30,133 & 19,012 \\
\hline R-squared & 0.021 & 0.021 & 0.020 & 0.020 & 0.019 & 0.010 & 0.010 & 0.010 & 0.009 & 0.011 \\
\hline
\end{tabular}

Notes: Heteroskedacticity-robust standard errors clustered by day of birth are in parentheses. ***,**, and * indicate statistical significance at the 1,5 , and 10 percent level respectively. After is an indicator for individuals born after January 1 . Treatment is an indicator that equals 1 for cohorts who experienced an education expansion. 
Appendix Table 11: Effect of Educational Expansion on Smoking and Chronic Conditions

\begin{tabular}{|c|c|c|c|c|c|c|c|c|c|c|}
\hline \multicolumn{6}{|c|}{$\begin{array}{c}\text { dependent variable: smoking (columns 1-5) and chronic conditions (columns 7-12) } \\
\text { Full sample - smoking }\end{array}$} & \multicolumn{5}{|c|}{ Full sample - chronic condition } \\
\hline \multirow[t]{2}{*}{ Bandwidth (months) } & 6 & 5 & 4 & 3 & 2 & 6 & 5 & 4 & 3 & 2 \\
\hline & (1) & (2) & (3) & (4) & (5) & (6) & (7) & (8) & (9) & $(10)$ \\
\hline \multicolumn{11}{|l|}{ Treated years } \\
\hline After & $\begin{array}{l}0.0092^{*} \\
{[0.0051]}\end{array}$ & $\begin{array}{l}0.0092 * \\
{[0.0044]}\end{array}$ & $\begin{array}{l}0.0095^{* *} \\
{[0.0040]}\end{array}$ & $\begin{array}{l}0.0117 * * \\
{[0.0041]}\end{array}$ & $\begin{array}{l}0.0067 \\
{[0.0045]}\end{array}$ & $\begin{array}{l}0.0099 * * \\
{[0.0044]}\end{array}$ & $\begin{array}{l}0.0101^{*} \\
{[0.0050]}\end{array}$ & $\begin{array}{l}0.0107^{*} \\
{[0.0054]}\end{array}$ & $\begin{array}{l}0.0116^{*} \\
{[0.0054]}\end{array}$ & $\begin{array}{l}0.0151^{* *} \\
{[0.0050]}\end{array}$ \\
\hline \multicolumn{11}{|l|}{ Sample size } \\
\hline \multirow[t]{2}{*}{ R-squared } & 113,367 & 94,611 & 73,720 & 53,302 & 32,486 & 113,367 & 94,611 & 73,720 & 53,302 & 32,486 \\
\hline & 0.003 & 0.003 & 0.003 & 0.003 & 0.003 & 0.001 & 0.001 & 0.001 & 0.001 & 0.001 \\
\hline \multicolumn{11}{|l|}{ Control years } \\
\hline After & $\begin{array}{c}0.0017 \\
{[0.0060]}\end{array}$ & $\begin{array}{c}-0.0006 \\
{[0.0064]}\end{array}$ & $\begin{array}{c}0.0007 \\
{[0.0071]}\end{array}$ & $\begin{array}{c}0.0031 \\
{[0.0058]}\end{array}$ & $\begin{array}{c}-0.0004 \\
{[0.0030]}\end{array}$ & $\begin{array}{c}0.0017 \\
{[0.0063]}\end{array}$ & $\begin{array}{c}0.0016 \\
{[0.0060]}\end{array}$ & $\begin{array}{c}0.0040 \\
{[0.0051]}\end{array}$ & $\begin{array}{c}0.0032 \\
{[0.0047]}\end{array}$ & $\begin{array}{c}0.0087 \\
{[0.0054]}\end{array}$ \\
\hline \multicolumn{11}{|l|}{ Sample size } \\
\hline \multirow[t]{2}{*}{ R-squared } & 64,852 & 54,126 & 42,289 & 30,730 & 19,048 & 64,852 & 54,126 & 42,289 & 30,730 & 19,048 \\
\hline & 0.001 & 0.001 & 0.001 & 0.001 & 0.001 & 0.001 & 0.001 & 0.000 & 0.001 & 0.001 \\
\hline \multicolumn{11}{|l|}{ All years } \\
\hline After & $\begin{array}{c}0.0017 \\
{[0.0060]}\end{array}$ & $\begin{array}{c}-0.0006 \\
{[0.0064]}\end{array}$ & $\begin{array}{c}0.0007 \\
{[0.0071]}\end{array}$ & $\begin{array}{c}0.0031 \\
{[0.0058]}\end{array}$ & $\begin{array}{c}-0.0004 \\
{[0.0030]}\end{array}$ & $\begin{array}{c}0.0017 \\
{[0.0063]}\end{array}$ & $\begin{array}{c}0.0016 \\
{[0.0060]}\end{array}$ & $\begin{array}{c}0.0040 \\
{[0.0051]}\end{array}$ & $\begin{array}{c}0.0032 \\
{[0.0047]}\end{array}$ & $\begin{array}{c}0.0087 \\
{[0.0054]}\end{array}$ \\
\hline After*Treatment & $\begin{array}{c}0.0075 \\
{[0.0066]}\end{array}$ & $\begin{array}{c}0.0097 \\
{[0.0073]}\end{array}$ & $\begin{array}{c}0.0088 \\
{[0.0085]}\end{array}$ & $\begin{array}{c}0.0086 \\
{[0.0089]}\end{array}$ & $\begin{array}{c}0.0071 \\
{[0.0075]}\end{array}$ & $\begin{array}{c}0.0082 \\
{[0.0079]}\end{array}$ & $\begin{array}{c}0.0084 \\
{[0.0081]}\end{array}$ & $\begin{array}{c}0.0068 \\
{[0.0083]}\end{array}$ & $\begin{array}{c}0.0083 \\
{[0.0074]}\end{array}$ & $\begin{array}{c}0.0064 \\
{[0.0093]}\end{array}$ \\
\hline Sample size & 178,219 & 148,737 & 116,009 & 84,032 & 51,534 & 178,219 & 148,737 & 116,009 & 84,032 & 51,534 \\
\hline $\mathrm{R}$-squared & 0.006 & 0.006 & 0.006 & 0.006 & 0.006 & 0.001 & 0.001 & 0.001 & 0.001 & 0.001 \\
\hline
\end{tabular}

Notes: Heteroskedacticity-robust standard errors clustered by day of birth are in parentheses. $* * *, * *$, and * indicate statistical significance at the 1,5 , and 10 percent level respectively. After is an indicator for individuals born after January 1 . Treatment is an indicator that equals 1 for cohorts who experienced an education expansion. 